\title{
Ionomic Approaches for Discovery of Novel Stress-Resilient Genes in Plants
}

\author{
Sajad Ali ${ }^{1}$, Anshika Tyagi ${ }^{2}$ and Hanhong Bae ${ }^{1, *}$ \\ 1 Department of Biotechnology, Yeungnam University, Gyeongsan 38541, Korea; sajadali84@gmail.com \\ 2 National Institute for Plant Biotechnology, New Delhi 110012, India; tyagi.anshika9@gmail.com \\ * Correspondence: hanhongbae@ynu.ac.kr; Tel.: +82-53-810-3031
}

Citation: Ali, S.; Tyagi, A.; Bae, H. Ionomic Approaches for Discovery of Novel Stress-Resilient Genes in Plants. Int. J. Mol. Sci. 2021, 22, 7182. https://doi.org/10.3390/ijms22137182

Academic Editor: Juan Manuel Ruiz Lozano

Received: 27 April 2021

Accepted: 29 June 2021

Published: 2 July 2021

Publisher's Note: MDPI stays neutral with regard to jurisdictional claims in published maps and institutional affiliations.

Copyright: (c) 2021 by the authors. Licensee MDPI, Basel, Switzerland. This article is an open access article distributed under the terms and conditions of the Creative Commons Attribution (CC BY) license (https:// creativecommons.org/licenses/by/ $4.0 /)$.

\begin{abstract}
Plants, being sessile, face an array of biotic and abiotic stresses in their lifespan that endanger their survival. Hence, optimized uptake of mineral nutrients creates potential new routes for enhancing plant health and stress resilience. Recently, minerals (both essential and non-essential) have been identified as key players in plant stress biology, owing to their multifaceted functions. However, a realistic understanding of the relationship between different ions and stresses is lacking. In this context, ionomics will provide new platforms for not only understanding the function of the plant ionome during stresses but also identifying the genes and regulatory pathways related to mineral accumulation, transportation, and involvement in different molecular mechanisms under normal or stress conditions. This article provides a general overview of ionomics and the integration of high-throughput ionomic approaches with other "omics" tools. Integrated omics analysis is highly suitable for identification of the genes for various traits that confer biotic and abiotic stress tolerance. Moreover, ionomics advances being used to identify loci using qualitative trait loci and genome-wide association analysis of element uptake and transport within plant tissues, as well as genetic variation within species, are discussed. Furthermore, recent developments in ionomics for the discovery of stress-tolerant genes in plants have also been addressed; these can be used to produce more robust crops with a high nutritional value for sustainable agriculture.
\end{abstract}

Keywords: ionomics; biotic stress; abiotic stress; gene identification; QTL mapping; omics; elemental analysis

\section{Introduction}

In modern agriculture, abiotic and biotic stresses are the leading causes of reduced crop yield and productivity, resulting in significant economic losses [1]. In the future, global warming will intensify the impact of these stresses on sustainable agriculture and pose a serious threat to food security [2,3]. Additionally, it will also lead to a mounting concurrence of biotic and abiotic stress combinations in crops, which would be detrimental to their growth and productivity [4]. On the other hand, nutritional security is becoming one of the major challenges for researchers developing not only stress-resilient crops but also biofortified crops to tackle malnutrition. Therefore, a deep understanding of crop responses to multiple stressors is important for improving crop resilience in sustainable agriculture [5]. Plants undergo a series of morphological, biochemical, physiological, and molecular modifications in order to combat the effects of environmental stresses [6]. The functioning of these stress-resilient pathways in plants is primarily dependent on the availability and accumulation of minerals. Recently, ions (both essential and non-essential) have been identified as key players in plant stress biology due to their multifaceted functions, thereby creating new areas of investigation [7]. In this regard, ionomics, a multidisciplinary field, can provide new crop platforms for identifying genes and their regulatory pathways related to mineral accumulation, transportation, cross-talk, and stress resilience. Furthermore, such platforms will enable the development of ionomics-based biomarkers that can assess whether a plant has attained a certain biochemical or physiological state under 
different stresses and environmental conditions. For example, Zn deficiency-responsive genes/biomarkers like ZIP4 and IRT3 have been reported in Arabidopsis that will be useful proxies for measuring zinc deficiency tolerance [8]. Plants need many inorganic mineral elements to complete their life cycle, as well as to maintain healthy growth. Minerals play a vital role in various biological functions as cofactors, macromolecules, osmotic solutes, and ionizing species [9]. Generally, minerals are classified as macronutrients and micronutrients, or essential elements based on the quantity required by plants. Macronutrients, namely, potassium $(\mathrm{K})$, nitrogen $(\mathrm{N})$, phosphorus $(\mathrm{P})$, calcium $\left(\mathrm{Ca}^{2+}\right)$, magnesium $(\mathrm{Mg})$, and sulfur (S), are required by plants in higher quantities $(>0.1 \%$ of dry weight). On the other hand, micronutrients such as zinc $(\mathrm{Zn})$, manganese $(\mathrm{Mn})$, iron $(\mathrm{Fe})$, chlorine $(\mathrm{Cl})$, copper $(\mathrm{Cu})$, boron (B), molybdenum (Mo), and nickel (Ni) are required in smaller quantities $(<0.1 \%$ of dry weight) [10]. In addition to these essential elements, plants take up many non-essential elements such as aluminum $(\mathrm{Al})$, silicon $(\mathrm{Si})$, selenium $(\mathrm{Se})$, sodium $\left(\mathrm{Na}^{+}\right)$, cobalt $(\mathrm{Co})$, gallium (Ga), cadmium (Cd), and arsenic (As) [11]. At a specific uptake level, some of these non-essential elements are beneficial for certain plant species. For example, $\mathrm{Si}$, which was recently declared a useful element for plant growth by the International Plant Nutrition Institute (IPNI), confers incredible benefits onto plants, particularly under stress conditions (http:/ / www.ipni.net/nutrifacts-northamerican, accessed on 1 April 2021). Elements such as $\mathrm{Cd}$ and As have no biological function and are not required by plants, but are often taken up, and cause severe toxicity [12]. However, plants have developed a variety of protective mechanisms to cope up heavy metal stresses, which includes decreased heavy metal absorption, sequestration of metal into vacuoles, binding phytochelatins/metallothioneins, and activation of various antioxidants [13]. Crops are the principal sources of essential mineral nutrients for humans and animals. Therefore, understanding their elemental composition is essential for healthy crop production.

Ionomics is the study of metal, non-metal, and metalloid compositions in living organisms using high-throughput elemental analysis technologies such as inductively coupled plasma-atomic emission spectroscopy (ICP-AES) and ICP-mass spectrometry (ICP-MS) [14]. In a broader sense, it is the study of an organism's ionome and is aimed at quantifying as many elements as possible in individual samples and at determining how metabolism, genetics, development, and the environment influence the elemental composition of target organs, tissues, and cell types [15]. The concept of the ionome was introduced about 10 years ago, and since then, significant progress has been made in the area of ionomics, mainly because of its integration with genetics and other high-throughput tools to identify the genes that regulate the ionome $[16,17]$. The initial work on ionomics in the model plant Arabidopsis thaliana has become the key for its expansion to agriculturally relevant crops [16]. Ionomics has been used to investigate the role of minerals in different economically important crops, namely, Glycine max [18], Zea mays [19], Oryza sativa [20], Brassica napus [21], Olea europaea [22], and Vitis vinifera [23]. It has wide applications for studies on nutrient utilization, environmental monitoring, biofortification, and food safety [15]. In addition, this high-throughput tool is efficient for revealing not only interdependency among various mineral elements but also the genetic factors that regulate mineral transport and homeostasis in plants [24,25]. Moreover, it may also be used to investigate the effects of phylogenetics and the climate on plant mineral accumulation [26]. Ionomics has been applied extensively in plant biology, not just for human food requirements but also to study plant developmental and stress biology. Shakoor et al. [27] revealed how ionomics could tackle malnutrition and improve food safety. They performed ionomic analyses of staple food crops such as cereals and beans. Ionomics, when used in conjunction with other high-throughput tools, such as proteomics, transcriptomics, and metabolomics, has the ability to bridge the gap between the understanding of a genotype and the phenotype it regulates [14]. In ionomics, mutant screening and natural variation are useful to identify genes and alleles that are essential for elemental accumulation and variations in the ionomes of different genotypes $[28,29]$. The most comprehensive data on ionomics applications have been generated using $A$. thaliana through a mega project at the Purdue Ionomics facility 
(http://www.ionomicshub.org, accessed on 1 April 2021). This venture has played an outstanding role in the identification of numerous ionome regulatory genes [30]. There are total 1764 genes from A. thaliana (136), O. sativa (141), Medicago truncatula (176), Triticum aestivum (267), Z. mays (152), G. max (268), Populus trichocarpa (197), Sorghum bicolor (135), Setaria italica (146), and Setari viridis (146), which have been identified as ionome regulatory genes. Some of the primary genes and their elemental targets have been shown in Table 1. The Purdue Ionomics Information Management System (PiiMS) has been used to record all data generated from such projects (http:/ / www.ionomicshub.Org, accessed on 1 April 2021). In plant stress biology, ionomics-based biomarkers can help determine whether a plant has attained a specific biochemical or physiological state under various unfavorable environmental conditions. Subsequently, they can also help screen plants that are more prone to abiotic and biotic stresses; this is not possible using other high-throughput tools. In addition, ionomics has revealed genes that govern natural variation in the plant ionome and play a crucial role in stress resilience. In this review, we focus on the role of ionomics in crop improvement, particularly in improving abiotic and biotic stress tolerance.

Table 1. List of primary genes and their elemental targets that affect plant ionome in different plant species.

\begin{tabular}{|c|c|c|c|c|c|}
\hline Species & $\begin{array}{c}\text { Total Ionome } \\
\text { Regulatory } \\
\text { Genes }\end{array}$ & Primary Gene Names & $\begin{array}{l}\text { Target } \\
\text { Elements }\end{array}$ & Tissues & References \\
\hline A. thaliana & 136 & $\begin{array}{c}\text { CNGC10, FRO2, MT1A, CPNIFS, } \\
\text { LPCAT1, PHO1;H3, PCR2, BTSL2, } \\
\text { FYVE1, CIPK23, ABCC1, CCC, NIP3;1, } \\
\text { AtNRT1.5/ AtNPF7.3, AtMSA1, myb72, } \\
\text { NAS4, PEN3, AtIRT3, AtAPR2, } \\
\text { AtHMA5, AtAX1, MYB62, AtCITF1, } \\
\text { BTSL1, PHT1;9, NIP6;1, AtNRAMP1, } \\
\text { VIT1, SOS1/NHX7, ABH1, AtbZIP23, } \\
\text { AtHMA4, AtHAC1, AtNRAMP3, } \\
\text { AtMT4b, MOT1, FRU, ESB1, PHT1;5, } \\
\text { PHO2, ZAT11, FPN1, PHT1;4, } \\
\text { AtMTP11, AtMT4a, CNGC3, AtMTP1, } \\
\text { BOR1, VIH2, TSC10a, NIP7, } \\
\text { FRD3/MAN1, AtZIP1, myb10, CAX2, } \\
\text { mir169a, AtCTL1, BTS, AtATPS1, } \\
\text { bHLH34, PHO1, ZIFL2, PYE, AHA4, } \\
\text { CAX3, SULTR3;1, bHLH38, bHLH39, } \\
\text { AtMTP8, AtMTP3, MGT6, BOR2, } \\
\text { GA1, AtHKT1;1, NIP5;1, HAK5, } \\
\text { bHLH104, OPT3, IRT1, GSH1, YSL1, } \\
\text { AtPHR1, AtHMA2, AtHMA3, CBL10, } \\
\text { AtbZIP19, HMA1, NaKR1, ACR2, } \\
\text { FPN2, MGT7, ZIF1, VIH1, } \\
\text { CNGC2/DND1, APG5, AtSPL7, } \\
\text { COPT5, SOS2, AtMfl1, PHT1;1, PCS1, } \\
\text { CNGC1, YSL3, ILR3, AtTSB1, } \\
\text { AtMYB36, COPT1, CPR5, AtNRAMP3 }\end{array}$ & $\begin{array}{c}\mathrm{K}, \mathrm{Ca}^{2+}, \mathrm{Mg}, \\
\mathrm{Fe}, \mathrm{Cd}, \mathrm{Zn}, \mathrm{As}, \\
\mathrm{Se}, \mathrm{S}, \mathrm{Zn}, \mathrm{P}, \mathrm{Mn}, \\
\mathrm{Co}, \mathrm{K}, \mathrm{Cd}, \mathrm{Na}, \\
\mathrm{NO}^{3-}, \mathrm{Mo}, \mathrm{Cu}, \\
\mathrm{B}, \mathrm{Ni}, \mathrm{Rb}, \mathrm{Cs}, \\
\mathrm{Li}, \mathrm{Sr}\end{array}$ & $\begin{array}{l}\text { Root, shoot, } \\
\text { leaf, seed }\end{array}$ & {$[29,31-39]$} \\
\hline
\end{tabular}


Table 1. Cont.

\begin{tabular}{|c|c|c|c|c|c|}
\hline Species & $\begin{array}{c}\text { Total Ionome } \\
\text { Regulatory } \\
\text { Genes }\end{array}$ & Primary Gene Names & $\begin{array}{c}\text { Target } \\
\text { Elements }\end{array}$ & Tissues & References \\
\hline O. sativa & 141 & $\begin{array}{c}\text { OsMTP9, OsHKT1;5, AKT1, } \\
\text { OsHORZ1, OsMGT1, OsHAC4, } \\
\text { OsHMA4, OsNIP1;1, OsYSL2, } \\
\text { OsYSL15, LSI1, OsMTP8.2, OsPHO1;2, } \\
\text { OsPT2, OsRab6a, OsMTP8.1, OsMIT, } \\
\text { OsNAS2, OsPHR2, OsHAK1, OsVIT1, } \\
\text { OsYSL9, OsYSL16, OsHMA5, OsZIP3, } \\
\text { OsABCC1, OsRMC, OsPCS1, OsZIP5, } \\
\text { OsHRZ2, OsPHO2, OsPCS2, SPDT, } \\
\text { OsHMA2, OsHKT2;1, TPKb, OsPHF1, } \\
\text { OsHMA3, NRAMP5, OsMOT1;1, } \\
\text { OsPRI1, OsNIP3;2, OsNIP3;3, } \\
\text { OsATX1, OsVIT2, ZIFL12, OsMIR, } \\
\text { OsbHLH133, OsBOR1, OsHRZ1 }\end{array}$ & $\begin{array}{c}\mathrm{Mn}, \mathrm{Na}^{+}, \mathrm{K}, \mathrm{Fe}, \\
\mathrm{Mg}, \mathrm{A} s, \mathrm{Cu}, \\
\mathrm{Mn}, \mathrm{Se}, \mathrm{P}, \mathrm{Zn}, \\
\mathrm{Cs}, \mathrm{Cd}, \mathrm{B}\end{array}$ & $\begin{array}{l}\text { Leaf, shoot, } \\
\text { root, seed }\end{array}$ & [40-52] \\
\hline T. aestivum & 267 & TaIPK1, Ta-PHR1, TaABCC13, HKT2;1 & $\begin{array}{l}\mathrm{Fe}, \mathrm{Zn}, \mathrm{P}^{\mathrm{N}} \mathrm{Na}^{+}, \\
\mathrm{Ca}^{2+}\end{array}$ & $\begin{array}{l}\text { Seed, root, } \\
\text { shoot }\end{array}$ & [53-57] \\
\hline Z. mays & 152 & ZmHKT1, YS1, YS3, ZmHAK5, TLS1 & $\mathrm{Na}^{+}, \mathrm{Fe}, \mathrm{K}, \mathrm{B}$ & $\begin{array}{c}\text { Leaf, root, } \\
\text { shoot, anthers }\end{array}$ & [58-63] \\
\hline M. truncatula & 176 & $\begin{array}{c}\text { MtMOT1.2, MtNramp1, MtMOT1.3, } \\
\text { MtCOPT1, MtMTP2, MtZIP6 }\end{array}$ & $\mathrm{Mo}, \mathrm{Fe}, \mathrm{Cu}, \mathrm{Zn}$ & Nodules & [64-69] \\
\hline
\end{tabular}

\section{Importance of Ionomics in Human Health, Food, and Agriculture}

Mineral nutrition is extremely important for the proper functioning of growth and developmental processes in living organisms. Seventeen elements are essential to plants; however, plants also take up and accumulate non-essential elements [11]. On the other hand, humans need at least 25 elements [70], which they mainly get from plants. In developing and developed countries, one of the widespread issues related to public health is mineral malnutrition; approximately two-thirds of the global population is at risk owing to a deficiency in one or more basic mineral elements [70]. One of the principal causes of malnutrition in developing countries is Fe and Zn deficiency [71]. Biofortification, as a strategy, could potentially address malnutrition through development of crops containing vital mineral elements and by enhancing their nutritional importance for humans [72] However, a complete understanding of the mechanism of mineral nutrient accumulation in grains is required before this technology can attain its full potential. In this context, high-throughput elemental profiling plays an important role in determining the capacity of mineral absorption genes in model and crop plants. Many mineral rich biofortified crops such as iron beans, iron pearl millet, zinc wheat, zinc rice, zinc maize, were successfully produced, tested, released, and marketed by HarvestPlus partnering institutions to farmers and consumers. The potential benefit of these biofortified crops has received widespread recognition for its ability to reduce the risk of $\mathrm{Zn}$ and Fe deficiency in underdeveloped nations [73]. Recently, Iron for Adolescent (FeFA) Girls, a new initiative to address malnutrition among adolescents, was recently launched by ICMR-National Institute of Nutrition (NIN) in association with International Crops Research Institute for the Semi-Arid Tropics (ICRISAT) for the development of Fe biomarkers using various omics approaches, including ionomics, to overcome iron deficiency known as anemia (https://www.icrisat.org/tag/fefa-girls/, accessed on 20 June 2021). Furthermore, only a few biofortified vegetable products are available on the market, such as selenium-enriched potatoes, carrots, and onions (Selenella), and iodine-biofortified potatoes 'Iodì' [74]. In contrast, certain crops pose a threat to public health, as they contain some toxic elements. The edible parts of crops contain a high concentration of toxic elements when plants are grown on cultivable land polluted with heavy metals and metalloids. In some Asian 
countries, many studies have been undertaken to address the issue of $\mathrm{Cd}$ contamination in rice grains, as it is very harmful to human health. Furthermore, crops grown in soil containing other metals such as $\mathrm{Cs}$ or $\mathrm{Sr}$ also pose a serious risk to humans [75]. Therefore, extensive information about the nature of different agriculturally important crops and their capacity to accumulate various elements through different routes, as well as complete information on their ionomes, is crucial for better human health. On the other hand, the deficiency of essential mineral nutrients causes dire symptoms, which can lead to complete mortality of plants under extreme conditions. However, when both essential and nonessential mineral elements are present at excess concentrations, they considerably reduce and inhibit plant growth [76] via biochemical, structural, and physiological changes [77]. In plants, heavy metal toxicity inhibits or alters many key biochemical or physiological traits such as photosynthesis, chlorosis, altered nutrient assimilation, low biomass accumulation, water balance, and senescence, eventually causing plant death [78]. In general, a plant can grow as long as the supply of a particular nutrient meets its needs. Hence, both mineral deficiency and excess have a major impact on food production and global food security. As ionomics can detect multiple elements, this technique is ideal for determining how changes in one element abundance influence others in plants. For example, numerous studies have demonstrated that increased $\mathrm{Si}$ concentrations can reduce Mn-mediated toxicity in a variety of crops $[79,80]$. Similarly, the impact of As on the nutrients present in rice plants can be determined using this method [81]. Based on previous findings, we have highlighted the importance of ionomics in modern agriculture (Figure 1).

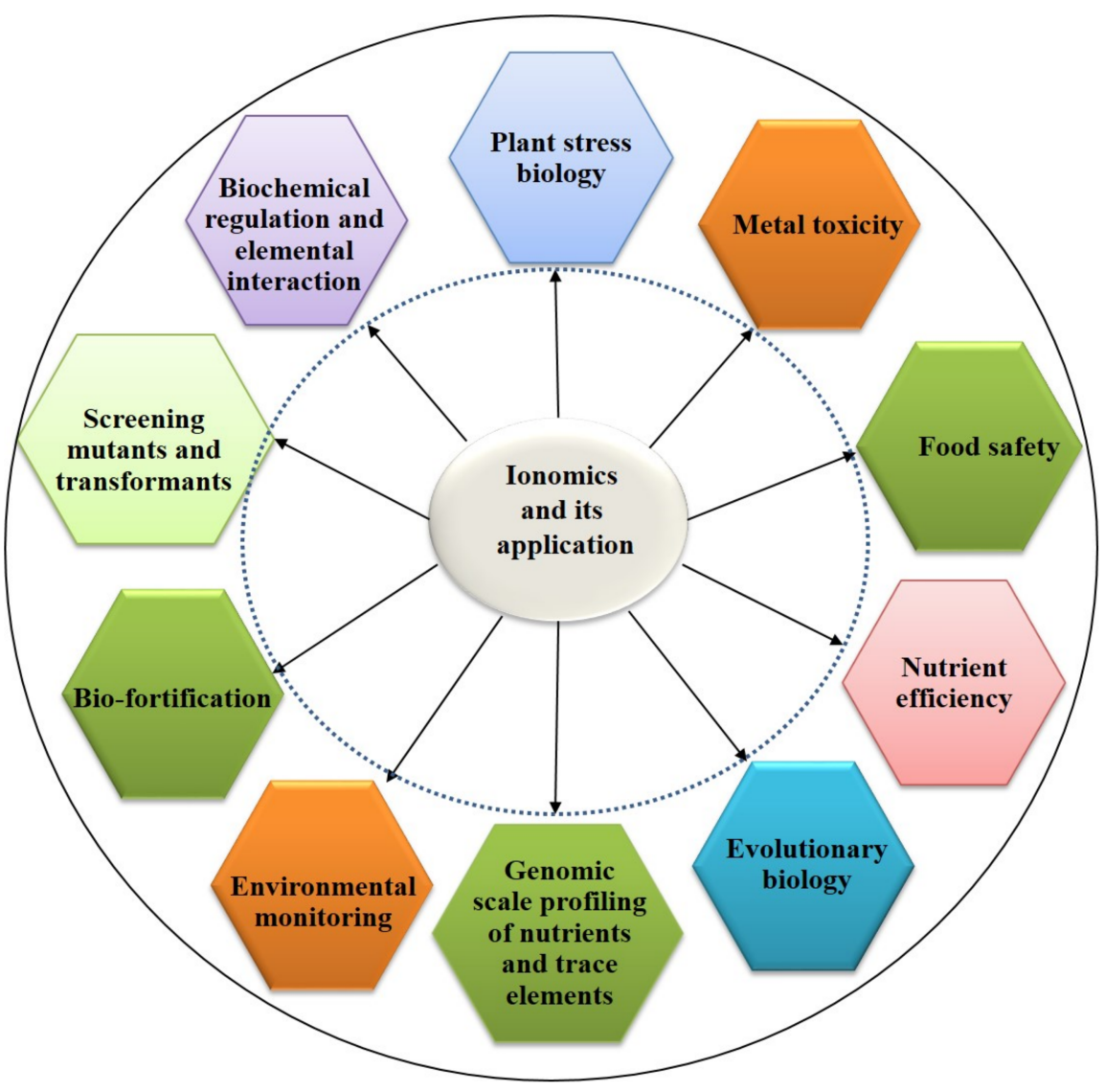

Figure 1. Overview of application of ionomics in human health and agriculture to identify different ions under diverse environmental conditions.

\section{Ionomics and Plant Biotic Stress}

Plants are invaded by a number of pathogens, including fungi, oomycetes, bacteria, viruses, and insects. Plants use a complex multi-tier defense system to combat pathogens, 
and this is often triggered by ions such as $\mathrm{Ca}^{2+}$. Owing to the advent of ionomics, it is currently well recognized that mineral nutrients play an important role during plantpathogen interactions. The minerals needed for pathogen survival are nearly identical to those required for plant survival [82]. Hence, the identification of new mediators of nutritional immunity in plants would require a thorough understanding of the dynamics and functional properties of mineral nutrients or the ionome during host-pathogen interactions. Generally, nutrients (micro and macro) play myriad roles in plants and are strictly regulated because many are toxic at high concentrations [83]. They boost structural strength and modulate various metabolic defense responses in host plants, thereby providing frontline defense against pathogens. The nutritional status of plants can be used to determine their susceptibility or resistance to pathogens [84]. Mineral nutrients are required to enhance growth and disease tolerance by activating key enzymes that generate prolific metabolites such as glucosinolates, lignin, callose, phytoalexins, and phenols. Previous studies have shown that hyper-accumulation of metal ions leads to effective disease resistance against Pseudomonas syringae in plants [85]. Interestingly, the concentration of minerals has a direct impact on the pathogen virulence or disease outcome. At low $\mathrm{N}$ concentrations, the impact of $P$. syringae disease severity was found to be low in tomato plants [86], whereas contrary results were observed for Xanthomonas vesicatoria infections [82]. $\mathrm{Ca}^{2+}$ ions are essential components of mineral nutrition that reduce disease severity or host susceptibility by inducing a large number of defense cascades, such as an increase in the rigidity of the cell membrane, because they are the key constituents of the cell wall (calcium galacturonates); hence, they increase cell stability [82]. In addition, $\mathrm{Ca}^{2+}$ significantly increases the activity of the antioxidant enzymes like superoxide dismutase (SOD), catalase (CAT), peroxidase (POD), and polyphenol oxidase (PPO) to scavenge reactive oxygen species (ROS) after pathogen infection [87]. This was demonstrated using plants that were $\mathrm{Ca}^{2+}$-deficient; many essential metabolites such as amino acids and sugars leaked out from the cytoplast region of the membrane to the apoplast, facilitating not only pathogen growth but also stimulation of disease progression [88]. Previous studies have revealed that hyper-accumulation of $\mathrm{Zn}$ ions is highly detrimental for bacterial pathogens, particularly Xanthomonas fastidiosa, because they play an important role in starch biosynthesis, protein structure, and protection of the plasma membrane from the effects of oxidative radicals [89]. In addition, $\mathrm{Zn}$ acts as a cofactor for countless enzymes that are mainly related to cell membrane integrity, hormone metabolism, and cell reproduction [83,90]. Similarly, Fe acts as a key source of competition between plants and pathogens during infection, to drive their cellular processes. Previous studies have shown that Fe deficiency in A. thaliana increases the expression of salicylic acid marker genes like PR1 that might play a key role in reducing the disease incidence and development after infection with Dickeya dadantii. In contrast, when $A$. thaliana was supplemented with $\mathrm{Fe}$, disease severity rose significantly because $D$. dadantii relies on its siderophore-mediated iron uptake system for systemic disease progression [91]. On the other hand, comparisons of leaf ionome between Xylella fastidiosa infected and non-infected olive trees show distinct differences, with $\mathrm{Zn}$ being the most discriminative ion between them and potentially serving as a biomarker for X. fastidiosa subsp. Pauca disease resistance [92]. In addition to their role in plant defense, minerals may have a significant impact on disease progression in plants because certain mineral nutrients help pathogen growth and survival. Nevertheless, they are obliquely involved, as they alter root exudates, determine microbial roles, and change the $\mathrm{pH}$ of the rhizosphere, and thus, have a huge impact on plant health and resilience [93]. The ionome has been used as an amalgamated phenotypic character to determine the relationship between pathogens and their host plants $[94,95]$. Previous ionomic studies have provided concrete evidence on the role of the ionome in disease resistance in lettuce against Xanthomonas campestris infections [96,97]. Attoma et al. [22] also showed that ionomics differentiates susceptibility and resistance traits in two olive cultivars that can further be used for identifying the target genes for olive disease management. Recent ionomics studies on grapes have revealed the intense restructuring of minerals in susceptible cultivars, indicating that minerals can play 
an essential protective role against pathogens [23]. On the other hand, pathogens employ a variety of defensive mechanisms to counteract the harmful effects of nutritional immunity. Previous ionomics studies have shown that the availability of nutrients has a significant impact on pathogen colonization in the corresponding host plants. For example, Xanthomonas oryzae pv. oryzae can force the host transcriptional machinery to activate and increase the expression levels of the $\mathrm{Cu}$ removal gene in rice, thereby facilitating its virulence [97]. Similarly, a bacterial pathogen of citrus greening disease hijacks host nutritional immunity by increasing the expression levels of small RNA linked with P starvation, thereby causing nutrient scarcity-like symptoms, a characteristic symptomatic feature in citrus [98]. In addition, sulfur (S) is an important constituent of plant defense compounds such as defensins, thionins, glucosinolates phytoalexins, glutathione, cysteine, and methionine, which are the major players of plant immune system. In addition, $\mathrm{S}$ based signaling molecules such as reactive sulfur species and hydrogen sulfide plays a key role in pathogen perception and signal transduction that are regulated by an array of plant defense hormones like SA, JA and ET [99]. For example, $S$ based antioxidant like GSH plays multifaceted role in SA mediated defense response in plants. The production of one of the prime signaling molecules like ROS, hydrogen peroxide $\left(\mathrm{H}_{2} \mathrm{O}_{2}\right)$ modifies the GSH/GSSG ratio and this change triggers $\mathrm{SA}$-associated plant defense signaling by inducing the SA synthetic gene isochorismate synthase 1 (ICS1) [100]. Similarly, overexpression of GSH1 in tobacco plants showed increased resistance to the bacterium Pst DC3000 [101]. Furthermore, Sbased pathogenesis-related proteins such as defesins and thionins are important antifungal proteins and when overexpressed in model and crop transgenic plants confer effective disease resistance against a wide range of pathogens. In $A$. thaliana $\mathrm{S}$ based receptor, CRKs (Cys-rich receptor-like kinases) are induced after treatment with bacterial flagellin22 but its mutation promotes disease progression and host susceptibility to bacterial pathogens. However, constitutive expression of CRKs like CRK28 increased disease resistance to bacterial pathogens in Arabidopsis [102]. Previous studies have shown that $S$ based fertilizers provides diseases resistance against an array of pathogens $[103,104]$. Many studies have revealed the effect of $\mathrm{K}$ on disease progression or resistance in different crops. For example, when strawberries were grown under low $\mathrm{K}$ levels they were found to be more resistant to Colletotrichum gloeosporioides than those grown under high $\mathrm{K}$ levels, because low K levels leads to the production of ROS, as well as the activation of the jasmonic acid and ethylene pathways, all of which lead to disease resistance [105]. However, contrary results were found in Cornus florida $\mathrm{L}$ which was more resistant to fungal pathogen Discula destructiva under high K levels [106]. Several mineral-related genes have been identified in various crops, and all of them play important roles during host-pathogen interactions and can be used to develop next-generation disease-resistant crops for sustainable agriculture (Table 2). Based on these findings, ionomics can provide both theoretical and practical insights into plant disease, etiology, early and accurate diagnosis, and nutritional therapy. Therefore, more ionomics studies on different crops are required to understand various host-pathogen interactions, as they will provide a wealth of knowledge on their function and allow for the screening of resistant genotypes. Hence, combining ionomics with other omics will create new opportunities for identifying potent resistant genes to improve disease resistance in crops via genome editing.

Table 2. List of genes identified in plants through high-throughput ionomics approaches.

\begin{tabular}{|c|c|c|c|c|c|}
\hline Candidate Gene & Species Name & Role in Stress & Function & Related Elements & Reference \\
\hline $\begin{array}{c}\text { FRD3 } \\
\text { Ferric Reductase } \\
\text { Defective3 }\end{array}$ & A. thaliana & Biotic & Citrate transporter & High $\mathrm{Mn}^{2+}$ and $\mathrm{Co}^{2+}$ & [107-109] \\
\hline $\begin{array}{c}\text { HKT1;1 } \\
\text { (High-affinity } \mathrm{K}+ \\
\text { transporter } 1 \text { ) }\end{array}$ & A. thaliana & Abiotic & Sodium transporter & High $\mathrm{Na}^{+}$ & {$[110,111]$} \\
\hline
\end{tabular}


Table 2. Cont.

\begin{tabular}{|c|c|c|c|c|c|}
\hline Candidate Gene & $\begin{array}{l}\text { Species } \\
\text { Name }\end{array}$ & Role in Stress & Function & Related Elements & Reference \\
\hline $\begin{array}{c}A P R 2 \\
\text { (Adenylylphosphosulfate } \\
\text { reductase) }\end{array}$ & A. thaliana & $\begin{array}{c}\text { Sulfur } \\
\text { Assimilation }\end{array}$ & $\begin{array}{l}\text { 50-Phosphosulfate } \\
\text { reductase }\end{array}$ & $\begin{array}{l}\text { High sulfate, } \mathrm{S}^{2-} \text {, and } \\
\mathrm{Se}^{2-}\end{array}$ & {$[25,112]$} \\
\hline $\begin{array}{c}\text { MOT1 } \\
\text { (Molybdate transporter } \\
1 \text { ) }\end{array}$ & A. thaliana & Biotic and abiotic & Molybdenum transporter & Low $\mathrm{Mo}^{2+}$ & {$[113,114]$} \\
\hline $\begin{array}{c}\text { FPN2 } \\
\text { (Ferroportin) }\end{array}$ & A. thaliana & Biotic and abiotic & $\begin{array}{l}\text { Ferroportin metal efflux } \\
\text { protein }\end{array}$ & $\mathrm{High} \mathrm{Co}^{2+}$ & {$[30]$} \\
\hline $\begin{array}{c}E S B 1 \\
\text { (Enhanced suberin1) }\end{array}$ & A. thaliana & Biotic and abiotic & $\begin{array}{c}\text { Dirigent } \\
\text { domain-containing } \\
\text { protein }\end{array}$ & $\begin{array}{c}\text { Low } \mathrm{Ca}^{2+} \text { and } \mathrm{Mn}^{2+} \\
\text { high } \mathrm{Na}^{+}, \mathrm{S}^{2-}, \mathrm{K}^{+} \\
\mathrm{As}^{3+}, \mathrm{Se}^{2-}, \text { and } \mathrm{Mo}^{2+}\end{array}$ & {$[115,116]$} \\
\hline $\begin{array}{c}\text { NaKR1 } \\
\begin{array}{l}\text { (Sodium potassium root } \\
\text { defective 1) }\end{array}\end{array}$ & A. thaliana & Biotic and abiotic & Metal binding protein & $\begin{array}{l}\text { High } \mathrm{Na}^{+}, \mathrm{K}^{+} \text {, and } \\
\mathrm{Rb}^{+}\end{array}$ & [117] \\
\hline $\begin{array}{c}\text { SGN1 } \\
\text { (Schengen3) }\end{array}$ & A. thaliana & Biotic and abiotic & Kinase & High $\mathrm{Mg}^{2+}$ & {$[117,118]$} \\
\hline $\begin{array}{c}\text { CPR5 } \\
\text { (Constitutive Expresser } \\
\text { of Pathogenesis Related } \\
\text { Genes 5) }\end{array}$ & A. thaliana & Biotic and abiotic & $\begin{array}{l}\text { Constitutive expression } \\
\text { of pathogen resistance }\end{array}$ & Low $\mathrm{K}^{+}$ & [119] \\
\hline $\begin{array}{c}\text { TSC10A } \\
\text { (Ketosphinganine } \\
\text { reductase) }\end{array}$ & A. thaliana & Biotic and abiotic & $\begin{array}{c}\text { 3- } \\
\text { Ketodihydrosphinganine } \\
\text { reductase }\end{array}$ & $\begin{array}{c}\text { Low } \mathrm{Mg}^{2+}, \mathrm{Ca}^{2+}, \mathrm{Fe}^{2+}, \\
\text { and } \mathrm{Mo}^{2+} ; \text { high } \mathrm{Na}^{+}, \\
\mathrm{K}^{+} \text {, and } \mathrm{Rb}^{+}\end{array}$ & [120] \\
\hline $\begin{array}{c}H M A 3 \\
\text { (Heavy Metal } \\
\text { ATPase) }\end{array}$ & A. thaliana & Biotic and abiotic & Heavy metal ATPase & Low $\mathrm{Cd}^{2+}$ & {$[121]$} \\
\hline $\begin{array}{c}\text { ATPS1 } \\
\text { (ATP sulfurylase 1) }\end{array}$ & A. thaliana & Biotic and abiotic & ATP sulfurylase & High sulfate & [122] \\
\hline $\begin{array}{c}\text { SGN3 } \\
\text { (Schengen3) }\end{array}$ & $\begin{array}{l}\text { Hordeum } \\
\text { vulgare }\end{array}$ & Biotic and abiotic & Receptor-like kinase & Low $\mathrm{K}^{+}$; high $\mathrm{Mg}^{2+}$ & [123] \\
\hline $\begin{array}{c}\text { ATQ1/HAC1 } \\
\text { (Arsenate reductase } \\
\text { QTL1/High Arsenic } \\
\text { Content 1) }\end{array}$ & A. thaliana & Biotic and abiotic & Arsenate reductase & High $\mathrm{As}^{3+}$ & [124] \\
\hline $\begin{array}{c}\text { MYB36 } \\
\text { (MYB Domain protein } \\
\text { 36) }\end{array}$ & A. thatiana & Biotic and abiotic & $\begin{array}{l}\text { MYB domain } \\
\text { transcription factor }\end{array}$ & $\begin{array}{c}\text { Low } \mathrm{Ca}^{2+}, \mathrm{Mn}^{2+} \text {, and } \\
\mathrm{Fe}^{2+} ; \\
\text { high } \mathrm{Na}^{+}, \mathrm{Mg}^{2+} \text {, and } \\
\mathrm{Zn}^{2+}\end{array}$ & [28] \\
\hline $\begin{array}{c}\text { GSL } \\
\text { (Glucosinolate) }\end{array}$ & $\begin{array}{l}\text { Arabidopsis } \\
\text { halleri and } \\
\text { Brassicaceae }\end{array}$ & Biotic and abiotic & $\begin{array}{l}\text { Increase in phloem of } \\
\text { young leaves against } \\
\text { Myzuspersicae protection } \\
\text { in Arabidopsis }\end{array}$ & $\mathrm{Zn}^{2+}, \mathrm{Cd}^{2+}$ & [125] \\
\hline $\begin{array}{c}A D \\
\text { (Alcohol } \\
\text { dehydrogenase) }\end{array}$ & $\begin{array}{l}\text { Cyamopsis } \\
\text { tetragonoloba }\end{array}$ & Biotic stress & $\begin{array}{l}\text { Up-regulate } \mathrm{Zn-binding} \\
\text { AD and making } \\
\text { pathogen resistant } \\
\text { cultivar }\end{array}$ & $\mathrm{Zn}^{2+}$ & [126] \\
\hline
\end{tabular}


Table 2. Cont

\begin{tabular}{|c|c|c|c|c|c|}
\hline Candidate Gene & Species Name & Role in Stress & Function & Related Elements & Reference \\
\hline $\begin{array}{c}C A \\
\text { (Carbonic } \\
\text { anhydrase) }\end{array}$ & A. thaliana & Biotic stress & $\begin{array}{l}\text { Act as salicylic acid } \\
\text { binding protein }\end{array}$ & $\mathrm{Zn}^{2+}$ & [127] \\
\hline $\begin{array}{c}\text { MT } \\
\text { (Metallothionein- } \\
\text { like } \\
\text { protein) }\end{array}$ & $\begin{array}{l}\text { Fagus } \\
\text { grandifolia }\end{array}$ & Biotic stress & $\begin{array}{l}\text { Resistant to fungal } \\
\text { infection }\end{array}$ & $\mathrm{Zn}^{2+}$ & [128] \\
\hline $\begin{array}{c}\text { Znf } \\
\text { (Zn finger) }\end{array}$ & T. aestivum & Biotic stress & $\begin{array}{l}\text { Key in the } \\
\text { R-gene-specific resistance } \\
\text { of plants to pathogens }\end{array}$ & $\mathrm{Zn}^{2+}$ & [129] \\
\hline $\begin{array}{c}\text { NHX8/ZTP1 } \\
(\mathrm{Na}+/ \mathrm{H}+ \\
\text { transporter/Zinc } \\
\text { transporter protein) }\end{array}$ & Malus halliana & Abiotic stress & $\begin{array}{l}\text { Saline-alkali stress } \\
\text { resistance }\end{array}$ & High $\mathrm{Na}^{+}$and $\mathrm{Fe}^{2+}$ & [130] \\
\hline $\begin{array}{c}A K T 1, M R S 2-4, \text { and } \\
\text { ZTP29 }\end{array}$ & M. halliana & Abiotic stress & $\begin{array}{c}\text { Saline-alkali stress } \\
\text { resistance }\end{array}$ & $\begin{array}{c}\text { Low } \mathrm{K}^{+}, \mathrm{Mg}^{2+} \text {, and } \\
\mathrm{Zn}^{2+}\end{array}$ & [130] \\
\hline $\begin{array}{c}A N T, A T P 2 A, C A L M \\
\text { and SOS2 }\end{array}$ & M. halliana & Abiotic stress & $\begin{array}{l}\text { Saline-alkali stress } \\
\text { resistance }\end{array}$ & $\begin{array}{c}\mathrm{Ca}^{2+} \text { signal } \\
\text { transduction }\end{array}$ & [130] \\
\hline
\end{tabular}

\section{Ionomics for Enhancement of Abiotic Stress Resilience in Crops}

In agriculture, abiotic stresses have a detrimental effect on plant growth and development and cause changes in metabolism, especially in the uptake and translocation of essential mineral nutrients. Numerous inorganic elements have been reported to combat abiotic stress in various crops $[131,132]$. Although they are toxic at high concentrations, mineral nutrients and trace elements play a crucial role under the safe limit to mitigate the negative effects of abiotic stresses, namely, toxicity caused by drought, salinity, and heavy metals [90]. $\mathrm{Ca}^{2+}$, a multifaceted secondary signaling messenger, is involved in almost all abiotic stress-mediated signaling in plants. Exogenous application of $\mathrm{Ca}^{2+}$ to crops induces effective tolerance to an array of abiotic stresses [133]. Pankovic [134] highlighted that $\mathrm{N}$ (7.5 mM) in Helianthus plants reduces the deleterious impact of Cd on photosynthesis by elevating the activity of the Rubisco enzyme and increasing the accumulation of defense protein. Similarly, P is instrumental in decreasing the metal-induced noxiousness in crop plants, as it lowers metal concentrations or limits metal movement via the formation of metal-phosphate complexes [135]. The addition of $60 \mathrm{mg} / \mathrm{kg} \mathrm{K}$ in T. aestivum, L significantly reduced the toxic effects caused by $\mathrm{Cd}$ by improving the concentration of non-enzymatic antioxidants (AsA and GSH). In another study, $\mathrm{K}$ supplementation alleviates $\mathrm{Cd}$ toxic effects in Gladiolus grandiflora L. by increasing the activity of antioxidant enzymes and proline, phenols, and flavonides [99]. Similarly, other mineral nutrients, including S, Mg, Zn, Fe, $\mathrm{Se}$, and $\mathrm{Si}$, have also been shown to lower heavy metal toxicity by boosting antioxidant activity, proline content, photosynthetic rate, and competing with heavy metal uptake, so minimizing their effect on cellular processes [90]. Under salt stress, GSH induced the ethylene level that ethylene plays a major role in stabilizing photosynthesis by maintaining the ROS accumulation, ion homeostasis, and mineral homeostasis and by elevating the antioxidant defense mechanism [136]. Similarly, S-induced GSH synthesis reduced ROS enhanced photosynthetic efficiency and growth in barley plants during salinity stress [137]. In maize plants, $\mathrm{S}$ based fertilizers improves drought tolerance by increasing not only the production of antioxidants but also increased rate of photosynthesis, stomatal conductance, and transpiration rate [138]. On the other hand, $\mathrm{K}$ plays a key role in drought tolerance in plants. For example, when sunflowers were grown under high $\mathrm{K}$ levels and drought conditions, stomatal closure is preceded from the guard cells via ethylene pathway and a higher photosynthetic rate was observed than under low $\mathrm{K}$ levels. In line with this, the 
ionomic profiling of guard cell reveals that $\mathrm{B}$ and $\mathrm{Zn}$ play a key role in stomata opening while $\mathrm{Mn}$ and $\mathrm{Cd}$ do in its closure, providing huge opportunities in understanding the significance of ions in the function of guard cells [139]. Previous studies have revealed that supplementation of $\mathrm{N}$ in wheat mitigates drought stress through the activation of an antioxidative defense system and higher photosynthetic activity [140]. Similarly, application of N on foliage and soil improved the growth and salinity tolerance of cotton [141]. In another study, application of $\mathrm{P}$ was found to combat salinity stress in wheat [142]. The effect of element uptake on different physiological components has been precisely evaluated in several studies to provide abiotic stress tolerance. Abiotic stress, such as salinity and/or heat, has previously been proven to cause alterations in nutrient intake. Generally, salinity stress increases $\mathrm{Na}^{+}$uptake which has an antagonistic effect on the absorption of other ions $\mathrm{K}^{+}, \mathrm{Ca}^{2+} \mathrm{Mg}^{+2}$, and $\mathrm{NO}^{3-}$, respectively. Similarly, an ionomic study in two recombinant inbred lines (RIL-66 low tolerant and RIL-76, high tolerant) of tomato illustrated a distinct profile between them with $\mathrm{K}^{+}$and $\mathrm{Mg}^{2+}$ comparatively higher in RIL-76 than RIL-66 during salinity and heat combination. The important finding of this study was that $\mathrm{K}^{+}$and $\mathrm{Mg}^{2+}$ can be used as heat and salt tolerant ionomic markers in tomato. However, no changes in $\mathrm{N}$ content were found between these the tolerant and sensitive RILs [143]. On the other hand, ionomic profiling of olive plants during drought stress shows how salicylic acid increases macro and micronutrients uptake, namely $\mathrm{P}, \mathrm{Fe}, \mathrm{Mn}$, and $\mathrm{Zn}$ that mitigates the effect of drought stress by improving plant water relations, stomatal regulation, cell membrane stability, osmolyte accumulation, water use efficiency, as well as photosynthesis [144]. Abbas et al. [145] performed ionomic and physiological analysis to study the physiological and ionomic variation in $\mathrm{Cd}$ tolerant and sensitive maize genotypes. It was found that $\mathrm{Cd}$ tolerant cultivar had considerably higher proline, phenolics, and antioxidant accumulation, as well as higher uptake and translocation of $\mathrm{N}, \mathrm{P}, \mathrm{K}, \mathrm{Ca}^{2+}, \mathrm{Mg}, \mathrm{Zn}$, and $\mathrm{Fe}$ from rhizosphere and root cell sap than $\mathrm{Cd}$ sensitive cultivar. These nutrients play a vital role in improving various physiological, biochemical, and molecular responses in plants for mitigating the harmful effects of stresses. Lee et al. [146] confirmed that canola genotypes with higher $S$ usage efficiency (SUE) could effectively withstand drought stress. Similarly, drought tolerance was also observed in wheat following increased $\mathrm{K}$ accumulation [147]. In a recent study, Jia et al. [130] performed ionomic and metabolomic analyses of Malus halliana during saline-alkali stress, which caused ion imbalance and $\mathrm{Na}^{+}$toxicity. These studies provided concrete evidence on the role of $\mathrm{Ca}^{2+}$-mediated signaling for maintaining $\mathrm{Na}^{+} / \mathrm{K}^{+}$homeostasis, as well as reducing stress-induced injury. They also highlighted the role of key genes, such as those of ATP-binding cassette $(A B C)$ transporters B1 and C10 ( $A B C B 1$ and $A B C C 10$, respectively), and NatA in mitigating salinity stress in M. halliana. Recently, ionomics profiling was used to investigate $\mathrm{F}$ tolerance in tea plants and it was found that $\mathrm{F}$ accumulation increases the production of $\mathrm{Na}^{+}, \mathrm{Fe}, \mathrm{Mn}$, and $\mathrm{Mo}$ in tea leaves that may provide the main positive charge to neutralize the negative charge from $\mathrm{F}$ thereby re-establishing ionic homeostasis [148]. On the other hand, F toxicity has been shown to reduce rice growth and yield by altering grain production [149]. Banerjee et al. [149] investigated the role of silicon nanoparticles (SiNPs) in ameliorating F toxicity in rice. They found that molecular priming with SiNPs effectively ameliorated injuries and improved yield by reducing $\mathrm{F}$ accumulation and increasing the content of non-enzymatic antioxidants such as glutathione, flavonoids, anthocyanins, and phenols in rice grains. Si priming also increases the levels of essential co-factors, namely, $\mathrm{Fe}, \mathrm{Zn}$, and $\mathrm{Cu}$, which further enhance the activity of antioxidant enzymes such as catalase, superoxide dismutase, ascorbate peroxidase, and guaiacol peroxidase, thereby inducing F tolerance. Similarly, Si plays an important role in mitigating salinity stress in crops by augmenting the accumulation and activity of various physiological and biochemical defense components that further improve stress tolerance [150]. These results provide the concrete evidence that ions not only have nutritional benefits in plants but also provide stress resilience. Previous ionomics studies on various crops during abiotic stresses resulted in the discovery of a number of stress-resistant genes that could be used to generate elite stress-tolerant plants (Table 1). 


\section{Quantitative Trait Loci (QTLs) and Genes Regulating Ionomic Traits}

The identification of genes/QTLs linked with the trait of interest is generally performed by QTL mapping and genome-wide association study (GWAS) of the crop species [151,152]. Ionomics evaluation of either a bi-parental mapping population or a diverse set of genotypes with molecular marker data enables efficient identification of the genomic loci governing a trait. The QTL mapping approach mostly uses a bi-parental mapping population $[153,154]$. In such a population, the profile of segregating molecular markers can correlate with any trait having variation among the parental lines. This approach can be used efficiently to identify loci for uptake and transport of different elements. The QTL mapping approach does not need any prior information about candidate genes and molecular pathways. Many QTL mapping studies have been carried out for the discovery of loci/genes associated with numerous ionomic traits (Table 3). For instance, QTLs for P accumulation [155], Cs accumulation [156] N uptake [157], and Al tolerance [158] have been identified in A. thaliana. Genetic mapping has also been used to identify the QTLs in rice, both in the leaves and grains, associated with 17 essential elements; 36 and 41 QTLs are associated with these elements in the leaves and grains, respectively. Buescher et al. [159] used high-throughput ICP-MS to analyze the amounts of various elements in 12 Arabidopsis accessions along with three recombinant inbred line (RIL) populations, which were developed under diverse environmental conditions. They observed significant differences among the accessions for most of the elements analyzed and found more than 100 QTLs for elemental accumulation in the RIL populations. It has been demonstrated that variations in the plant growth environment have a significant effect on the correlations among different elements and the QTLs controlling the ionome. QTL mapping studies for various ionomic traits have been performed for several crops such as T. aestivum [160], B. napus [161], and Z. mays [162]. Identification of the loci governing a trait has enormous importance in breeding applications, particularly in marker-assisted breeding. However, precise identification of the regulatory gene at the known locus using integrated omics tools is a prerequisite to understanding the underlying molecular mechanism [132,163]. For instance, once a QTL is defined, genomic data can be helpful to identify genes with the QTL region. However, most QTLs span thousands of bases and comprise hundreds of genes, which makes it challenging to determine the gene of interest [164]. Therefore, prior information about the gene functions in other plant species, or gene expression information, will be helpful to reduce the list to more favorable candidates. Earlier, a combination of QTL mapping and transcriptome profiling was found to be efficient in recognizing candidate genes [165-167]. Similarly, QTL mapping, genomic information, and gene expression data have been used by Induri et al. [168] to identify candidate genes in 16 QTLs linked to Cd accumulation in Populus spp.

Table 3. List of different analytical platforms used in ionomics to study plant ionomes and identify loci/QTLs governing uptake and distribution of different elements in plant tissues.

\begin{tabular}{|c|c|c|c|c|c|c|}
\hline Plant Species & $\begin{array}{l}\text { Number of } \\
\text { Genotypes }\end{array}$ & $\begin{array}{l}\text { Plant Tissue } \\
\text { Analyzed }\end{array}$ & $\begin{array}{l}\text { Ionomic Tool } \\
\text { Used for the } \\
\text { Elemental } \\
\text { Profiling }\end{array}$ & Elements Analyzed & $\begin{array}{l}\text { Number of Most } \\
\text { Significant Loci } \\
\text { Associated with } \\
\text { Ionomic Trait }\end{array}$ & Reference \\
\hline Soybean & 1653 & Seeds & ICP-MS & $\begin{array}{c}\mathrm{K}, \mathrm{P}, \mathrm{Zn}, \mathrm{Ca}^{2+}, \mathrm{Mg} \\
\mathrm{Na}^{+}, \mathrm{S}, \mathrm{Ni}, \mathrm{Fe}, \mathrm{Co}, \mathrm{Al}, \\
\mathrm{Cu}, \mathrm{Cd}, \mathrm{Mo} \mathrm{Se}, \mathrm{Rb}\end{array}$ & 573 unique SNPs & [169] \\
\hline Rice & 529 & Seeds & ICP-MS & $\begin{array}{c}\mathrm{Ca}^{2+}, \mathrm{P}, \mathrm{N}, \mathrm{Na}^{+}, \mathrm{Mg} \\
\mathrm{K}, \mathrm{Zn}, \mathrm{Cu}, \mathrm{B}, \mathrm{Cr}, \mathrm{Mo} \\
\mathrm{Cd}, \mathrm{Mn}, \mathrm{As}, \mathrm{Pb}, \mathrm{Co}\end{array}$ & 72 loci & [170] \\
\hline
\end{tabular}


Table 3. Cont.

\begin{tabular}{|c|c|c|c|c|c|c|}
\hline Plant Species & $\begin{array}{l}\text { Number of } \\
\text { Genotypes }\end{array}$ & $\begin{array}{c}\text { Plant Tissue } \\
\text { Analyzed }\end{array}$ & $\begin{array}{l}\text { Ionomic Tool } \\
\text { Used for the } \\
\text { Elemental } \\
\text { Profiling }\end{array}$ & Elements Analyzed & $\begin{array}{l}\text { Number of Most } \\
\text { Significant Loci } \\
\text { Associated with } \\
\text { Ionomic Trait }\end{array}$ & Reference \\
\hline Rice & 79 & Seeds & $\begin{array}{l}\text { Flow injection } \\
\text { spectropho- } \\
\text { tometer, and } \\
\text { ICPMS }\end{array}$ & $\begin{array}{c}\mathrm{P}, \mathrm{Si}, \mathrm{Fe}, \mathrm{Zn}, \mathrm{Cu}, \mathrm{Mn}, \\
\mathrm{Ni}, \mathrm{Pb}, \mathrm{Mo}, \mathrm{As}, \mathrm{Co}, \\
\mathrm{Cd}, \mathrm{Al}, \mathrm{Se}\end{array}$ & 36 QTLs & [171] \\
\hline $\begin{array}{l}\text { Common } \\
\text { bean }\end{array}$ & 84 & Seeds & ICP-AES & $\begin{array}{c}\mathrm{Fe}, \mathrm{S}, \mathrm{Ca}^{2+}, \mathrm{Mg}, \mathrm{Cu} \\
\mathrm{Zn}, \mathrm{Ni}, \mathrm{Mo}, \mathrm{Mn}, \mathrm{B}, \\
\mathrm{Cd}, \mathrm{Co}\end{array}$ & 21 QTLs & [172] \\
\hline $\begin{array}{l}\text { Monkey } \\
\text { flower }\end{array}$ & 168 & Leaves & ICP-MS & $\begin{array}{c}\mathrm{K}, \mathrm{P}, \mathrm{Ca}^{2+}, \mathrm{Na}^{+}, \mathrm{S}, \\
\mathrm{Zn}, \mathrm{Mg}, \mathrm{Fe}, \mathrm{Mn}, \mathrm{Cu}, \\
\mathrm{Rb}, \mathrm{B}, \mathrm{Sr}, \mathrm{Se}, \mathrm{As}, \mathrm{Cd}, \\
\mathrm{Ni}, \mathrm{Li}, \mathrm{Mo}\end{array}$ & 7 QTL & [173] \\
\hline Barley & 336 & Grains & ICP-MS & 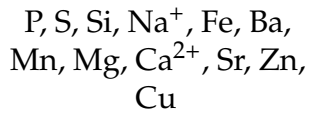 & 15 SNP loci & [174] \\
\hline
\end{tabular}

The main shortcoming of QTL mapping is its approach of utilizing the variance between two or limited genotypes (i.e., bi-parental or multi-parent crosses). However, in a natural population, allelic diversity is very high; GWAS is an approach to identify significant genotype-to-phenotype links in order to manipulate such allelic diversity [175-177]. GWAS has been proven to be an important approach for isolating QTLs or single genes responsible for imparting phenotypic variation in complex quantitative traits such as yield, quality, and biotic and abiotic stress tolerance [178]. Numerous natural alleles that regulate ionomic traits have been identified using the GWAS approach. An extensive GWAS was performed for $A$. thaliana, and 96-192 accessions involving 107 traits were analyzed in addition to the leaf concentrations of 18 elements [179]. Single nucleotide polymorphisms (SNPs) linked with $\mathrm{Na}$ in leaves in the genomic region encompassing HKT1;1, a gene encoding a Na transporter, were identified. Nevertheless, owing to the insufficient number of samples $(n=93)$ used in the study, significant SNPs were not identified for other elements. Therefore, in another study, a larger set of 349 accessions was used to describe a substantial portion of the species-wide diversity. The accession sets were genotyped with 250,000 SNPs and used for GWAS, which recognized four ionomic loci, including HKT1;1, a locus having high potential for ensuring salinity tolerance [111]. Chao et al. [121] combined GWAS with transgenic complementation and linkage mapping and showed that natural variation for $\mathrm{Cd}$ accumulation in $A$. thaliana leaves is directed by allelic diversity in the coding region of $H M A 3$. They also observed that in 349 accessions, a difference at the $H M A 3$ locus accounted for $30 \%$ of the overall variation in leaf $\mathrm{Cd}$ levels. Furthermore, $H M A 4$ has been reported to be an essential protein for $\mathrm{Cd}$ accumulation and tolerance in $A$. thaliana [180] and A. halleri [181]. In addition, GWAS has also been used to investigate the uptake of other elements such as As [124], S [124], Mo [179], and $\mathrm{Na}^{+}$[111].

In a recent investigation, Zhang et al. [182] performed GWAS of the concentrations of 13 elements in concert with a co-expression network. They identified 36 major QTLs related with 5 elemental concentrations that explained the phenotypic variation (PVE) from $18.35 \%$ to $27.56 \%$. Twenty-four QTLs were identified for B, six for $\mathrm{Na}^{+}$, three for S, two for $\mathrm{Cu}$, and one for $\mathrm{Zn}$. Furthermore, 110 non-redundant candidate genes were discovered, and one of them (arahy.KQD4NT) was a metal transporter. Descalsota-Empleo et al. [183] carried out QTL mapping for 4 agronomic traits and 13 grain elements in 2 doubled-haploid (DH) populations, using a $6 \mathrm{~K} \mathrm{SNP} \mathrm{chip.} \mathrm{Further,} 25$ epistatic interactions were uncovered for 2 agronomic traits and 7 mineral elements. Some polished rice $\mathrm{DH}$ lines with high Fe and $\mathrm{Zn}$ contents were identified, and they could be used as donors for generating rice cultivars 
having high $\mathrm{Zn}$ content and in marker-assisted selection. Multi-elemental traits are affected by both genetic and environmental factors, and thus, should be correlated [184]. A total of 191 SNPs were identified by targeting high-yield and low-metal-toxicity genes in rice [185]. This offered new insights into the genetic basis of ionomic and agronomic variations in rice, as well as a foundation for marker production in crop breeding and further research into reducing heavy metal toxicity and improving crop yields. Therefore, a combination of multivariate and univariate QTL tools will provide additional knowledge that will aid in better understanding of the covariation of elements in the ionome and help uncover more genes that regulate elemental accumulation in plants (Figure 2).

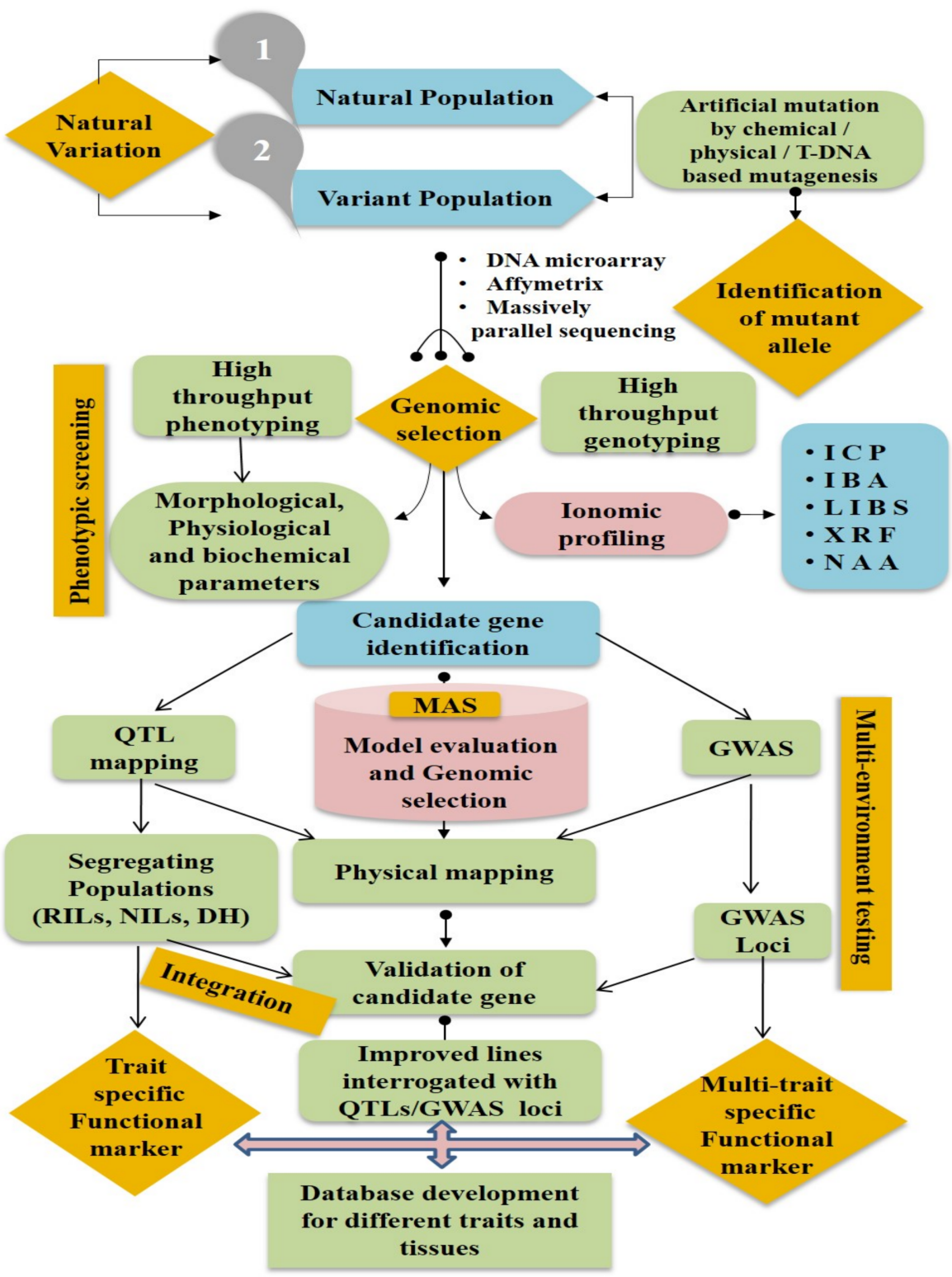

Figure 2. Quantitative trait locus (QTL) mapping and genome-wide association study (GWAS) for the identification of multi-trait specific biomarkers based on ionomic profiling and database development. RIL: recombinant inbred line; NIL: near isogenic line; DH: doubled haploid; MAS: marker-assisted selection; ICP: inductively coupled plasma; IBA: ion beam analysis; LIBS: laser-induced breakdown spectroscopy; XRF: X-ray fluorescence spectroscopy; NAA: neutron activation analysis.

\section{Tools and Technological Advancements for Ionomics Studies}

Initially, elemental profiling and distribution analysis were primarily used in environmental science and ecological studies. Ionomics has grown in popularity in the last decade 
as a tool for studying the metabolism and homeostasis of diverse ions or minerals in a variety of species, including plants and animals. However, this high-throughput ionomics tool requires sophisticated analytical instrumentation for quantitative and real-time measurement of elements in diverse tissue samples. Generally, techniques used in ionomics fall into two groups, which are mainly based on the atom electronic properties (emission, absorption, and fluorescence spectroscopy) or nuclear properties (radioactivity or atomic number) [14]. High-throughput analytical techniques such as liquid chromatography coupled to photodiode array/mass spectrometry (LC-PDA/MS), plasma optical emission spectroscopy (ICP-OES), liquid chromatography coupled to mass spectrometry (LC-MS), X-ray fluorescence (XRF), capillary electrophoresis coupled to mass spectrometry (CE-MS), gas chromatography coupled to mass spectrometry (GC-MS), nuclear magnetic resonance (NMR) spectroscopy, and Fourier transform-ion cyclotron resonance mass spectrometry (FT-ICR/MS) are sufficient and suitable for application in ionomics studies of plants [14]. Currently, ionomics relies on two high-throughput analytical techniques, namely ICPMS and ICP-AES, owing mainly to their multiple elemental profiling with high accuracy. ICP-MS has been the technique most suitable for multi-elemental trace analysis of environmental samples, in the last few decades. This technique has several advantages over other techniques, such as the ability to detect very low concentrations of non-metallic elements, and it is regularly used for the detection of up to 18 elements in ionomics studies [186]. The detection limit of the ICP-MS is as low as parts per trillion (PPT), which facilitates the detection of trace elements in a minimal amount of test material. The advantage of ICP-MS over atomic absorption spectroscopy (AAS) is that it can quantify multiple elements simultaneously. Heavy metal pollution in soil and water is mostly studied by ICP-MS [187]. The applicability of ICP-MS to study heavy metal stress has been demonstrated in several studies. For example, Ardini et al. [188] used ICP-MS to determine the ionome in wild and mutant Nicotiana langsdorffii during heavy metal and drought stress. Based on their findings they have determined 29 major and trace elements from various parts of the plants with high accuracy and precision. Recently, this high throughput tool, along with laser capture microdissection (LCM), was used for multi-element analysis of nanogram-sized biological samples [189]. Data obtained using ICP-MS can be used to identify the loci that govern the uptake and transport of elements [190]. Cost-effectiveness and accuracy of quantification make ICP-MS a choice platform for geneticists, ecologists, and plant breeders. On the other hand, ICP-AES is generally used in plant ionomics analysis predominantly for the detection of $\mathrm{Na}^{+}, \mathrm{K}, \mathrm{Ca}^{2+}, \mathrm{Mg}, \mathrm{P}, \mathrm{Zn}, \mathrm{Ba}, \mathrm{Fe}, \mathrm{Al}$, and $\mathrm{Mn}$, which are present at higher levels in plants [191]. Neutron activation analysis (NAA) is an appropriate method for elemental profiling in environmental and agricultural investigations [192]. In NAA, the nucleus of a sample (target) is bombarded with a beam of neutrons, leading to the formation of radioactive isotopes. As the radioactive decay life of each element is known, the elemental composition and concentration in each sample can be identified using this method. In addition, this method is highly sensitive for ion detection; therefore, it can be used for the detection of elements that are present in low quantities [193]. NAA has been proven to be an appropriate technique for elemental profiling because it is fast and reliable for small sample analysis. Previous studies have shown the application of NAA for determining various elements such as ( $\mathrm{Al} \mathrm{As}, \mathrm{Br}, \mathrm{Ca}^{2+}, \mathrm{Cd}, \mathrm{Ce}, \mathrm{Co}, \mathrm{Cr}, \mathrm{Cs}, \mathrm{Cu}, \mathrm{Fe}, \mathrm{K}$, $\mathrm{La}, \mathrm{Na}^{+}, \mathrm{Rb}, \mathrm{Sc}, \mathrm{Sm}, \mathrm{Sr}, \mathrm{Zn}, \mathrm{Lu}$, and Th) from different samples [194,195]. This technique has been proven to be an appropriate technique in ionomics studies where small samples of large numbers have to be analyzed. The general advantages of this method are that it can detect 60-70 elements with very good accuracy, it has a very large dynamic range, high selectivity and sensitivity, and it works with a single standard; however, it is the most time-consuming analytic technique [196]. However, expansion of other nonnuclear techniques like XRF and ICP-MS has led the decline of NAA method usage. Nonetheless, NAA is still useful in several applications, such as the analysis of various solid materials that are difficult to dissolve and the examination of samples to discover trace elements with low quantities [195]. X-Ray Fluorescence (XRF) is advantageous in environmental 
analysis. XRF spectroscopy is a multi-element technique, non-destructive, appropriate for several elements $(Z>18)$ with broad dynamic range, and economically practical. It can identify elements and determine concentrations in both liquid and solid samples [197]. $X$-rays (an external energy source) are used to illuminate a sample; in response, the sample emits X-ray photons of specific wavelengths that are used to determine the elemental composition. XRF has been used to identify various elements in $A$. thaliana [198]. Recent advances in XRF technology have made it more convenient to use in the field. Portable $\mathrm{XRF}$ (pXRF) is capable of quantifying a broad range of elements, including light elements such as $\mathrm{Mg}$, Al, and $\mathrm{Si}$ [199]. An element such as $\mathrm{Si}$, which is known to provide benefits against several abiotic stresses, can be efficiently quantified with pXRF [200,201]. XRF spectroscopy is frequently used for soil analysis and can also be utilized in plant analysis. Generally, elements such as $\mathrm{Al}(\mathrm{Z}=13), \mathrm{K}(\mathrm{Z}=19), \mathrm{Ca}^{2+}(\mathrm{Z}=20), \mathrm{Al}(\mathrm{Z}=13), \mathrm{Ti}(\mathrm{Z}=22), \mathrm{V}$ $(Z=23), M n(Z=25), C u(Z=29), Z n(Z=30)$, and $\operatorname{Sr}(Z=38)$ can be determined using this method; in some cases, $\mathrm{S}(\mathrm{Z}=16), \mathrm{Cl}(\mathrm{Z}=17)$, and $\mathrm{Pb}(\mathrm{Z}=82)$, as well as rarely, $\mathrm{P}(\mathrm{Z}=15)$, As $(Z=33)$, and Co $(Z=27)$, can be determined depending on the concentrations in the samples. Owing to advancements in ionomics tools, synchrotron-based $X$-ray fluorescence microscopy (SXRF) has become one of the most important elemental profiling analysis methods because it provides hidden information about ion homeostasis, such as how ions are taken up, transported, and processed in different cellular compartments [202]. This flexible technique also provides information about transporters and their effects on the element's bioavailability. It also employs a multi-elemental detection system that collects data on several metals simultaneously without affecting the sample's original state; hence, it can be used for multi-element analysis [203]. This high throughput tool has been used in various elemental profiling studies including the examination of $\mathrm{Zn}$ in mycorrhizae-infected tomato roots [204]; Se in the roots of onion [205], and Fe, Zn, Mn, and Cu distribution in rice grains [206,207]. Further, high throughput analytical techniques used in elemental profiling in different plants is shown in Table 4.

Table 4. Shows the high-throughput analytical techniques commonly used for ionomics in plants.

\begin{tabular}{|c|c|c|c|c|c|c|}
\hline Plant species & Ion & Medium & $\begin{array}{l}\text { Tissue } \\
\text { Used }\end{array}$ & Platform & Study & Reference \\
\hline A. thaliana & $\begin{array}{c}\mathrm{B}, \mathrm{Ca}^{2+}, \mathrm{Mg}, \mathrm{Mn}, \mathrm{Fe} \\
\mathrm{Cu}, \mathrm{Zn}, \mathrm{P}, \mathrm{Co}, \mathrm{Mo}, \mathrm{As}, \\
\mathrm{Cd}\end{array}$ & Pot assay & Leaf & ICP-MS & $\begin{array}{c}\text { Fe and } \mathrm{P} \\
\text { homeostasis }\end{array}$ & [24] \\
\hline $\begin{array}{c}\text { Rice } \\
\text { (O. sativa) }\end{array}$ & $\begin{array}{c}6 \text { elements } \\
\mathrm{K}, \mathrm{Ca}^{2+}, \mathrm{Mn}, \mathrm{Zn}, \mathrm{Cu}, \\
\mathrm{Fe}\end{array}$ & $\begin{array}{l}\text { Lab/tissue } \\
\text { culture } \\
\text { condition }\end{array}$ & Seed & SXRF & $\begin{array}{l}\text { Characterization of } \\
\text { a new } \mathrm{Zn} \text { plasma } \\
\text { membrane } \\
\text { transporter, OsZIP7 }\end{array}$ & [208] \\
\hline $\begin{array}{c}\text { Apple } \\
(M . \text { halliana })\end{array}$ & $\begin{array}{c}\mathrm{Ca}^{2+}, \mathrm{Fe}, \mathrm{Zn}, \mathrm{Mg}, \mathrm{Mn}, \\
\mathrm{Na}^{+}, \mathrm{K}, \mathrm{Cu}, \mathrm{Cl}\end{array}$ & Hydroponics & Seedlings & $\begin{array}{l}\text { ICP-OES, Ion } \\
\text { exchange chro- } \\
\text { matography, } \\
\text { LC-MS }\end{array}$ & $\begin{array}{c}\text { To study } \\
\text { saline-alkali stress } \\
\text { in } M \text {. halliana } \\
\text { seedlings }\end{array}$ & [130] \\
\hline $\begin{array}{l}\text { Soybean } \\
\text { (G.max) }\end{array}$ & $\begin{array}{c}\mathrm{B}, \mathrm{Na}^{+}, \mathrm{Mg}, \mathrm{Al}, \mathrm{P}, \mathrm{S}, \mathrm{K} \\
\mathrm{Ca}^{2+}, \mathrm{Mn}, \mathrm{Fe}, \mathrm{Co}, \mathrm{Ni} \\
\mathrm{Cu} \mathrm{Zn}, \mathrm{As}, \mathrm{Se}, \mathrm{Rb}, \mathrm{Mo}, \\
\text { and } \mathrm{Cd}\end{array}$ & $\begin{array}{l}\text { Field } \\
\text { conditions }\end{array}$ & Seed & $\begin{array}{l}\text { ICP-MS and } \\
\text { SoySNP50k } \\
\text { chip data }\end{array}$ & $\begin{array}{c}\text { Identified } \\
\text { candidate SNPs } \\
\text { controlling } \\
\text { elemental } \\
\text { accumulation as } \\
\text { well as lines with } \\
\text { extreme elemental } \\
\text { accumulation } \\
\text { phenotypes. }\end{array}$ & [169] \\
\hline $\begin{array}{l}\text { Soybean } \\
\text { (G. max) }\end{array}$ & $\mathrm{Se}, \mathrm{Cu}, \mathrm{Fe}, \mathrm{Mn}$ & $\begin{array}{c}\text { Field } \\
\text { conditions }\end{array}$ & Seed & ICP-MS & $\begin{array}{l}\mathrm{C} / \mathrm{N} \text { and other } \\
\text { elements }\end{array}$ & [209] \\
\hline
\end{tabular}


Table 4. Cont.

\begin{tabular}{|c|c|c|c|c|c|c|}
\hline Plant species & Ion & Medium & Tissue Used & Platform & Study & Reference \\
\hline $\begin{array}{c}\text { Tomato } \\
\text { (Solanum } \\
\text { lycopersicum) }\end{array}$ & $\mathrm{Na}^{+}$and $\mathrm{Cl}$ & Sand culture & Root, stem and leaf & AAS & $\begin{array}{l}\text { Role of } \mathrm{Si} \text { in } \\
\text { mitigating abiotic } \\
\text { stress }\end{array}$ & [210] \\
\hline $\begin{array}{c}\text { Lotus } \\
\text { (Lotus japonicus) }\end{array}$ & $\begin{array}{c}15 \text { elements } \\
\mathrm{B}, \mathrm{Cd}, \mathrm{Ca}^{2+}, \mathrm{Cu}, \mathrm{Cs}, \mathrm{Fe}, \\
\mathrm{Pb}, \mathrm{Mg}, \mathrm{Mn}, \mathrm{Mo}, \mathrm{Ni}, \mathrm{K}, \\
\mathrm{Na}^{+}, \mathrm{Sr} \text { and } \mathrm{Zn}\end{array}$ & Hydroponics & Seeds & ICP-MS & $\begin{array}{l}\text { To investigate the } \\
\text { accumulation of } \\
15 \text { elements in } \\
\text { shoots of mutants } \\
\text { of } L \text {. japonicus }\end{array}$ & [211] \\
\hline $\begin{array}{c}\text { Barley } \\
\text { (H. vulgare) }\end{array}$ & $\begin{array}{c}\mathrm{Na}^{+}, \mathrm{K}, \mathrm{Ca}^{2+}, \mathrm{Mg}, \mathrm{P}, \mathrm{S} \\
\mathrm{Cu}, \mathrm{Fe}, \mathrm{Mn} \text {, and } \mathrm{Zn}\end{array}$ & $\begin{array}{l}\text { Hydroponics } \\
\text { and pot } \\
\text { conditions }\end{array}$ & Germination/seedlings & ICP-OES & $\begin{array}{l}\text { Salinity stress in } \\
\text { barley }\end{array}$ & [212] \\
\hline $\begin{array}{l}\text { Breckland } \\
\text { wormwood } \\
\text { (Artemisia } \\
\text { campestris) }\end{array}$ & $\begin{array}{c}21 \text { elements } \\
\text { Higher: } \mathrm{K}, \mathrm{Ca}^{2+}, \mathrm{Fe}, \mathrm{Na}^{+} \\
\mathrm{As}, \mathrm{Ba}, \mathrm{Br}, \mathrm{Ca}, \mathrm{Ce}, \mathrm{Co}, \\
\mathrm{Cr}, \mathrm{Cs}, \mathrm{Eu}, \mathrm{Fe}, \mathrm{Hf}, \mathrm{K}, \mathrm{La} \text {, } \\
\mathrm{Na}, \mathrm{Rb}, \mathrm{Sb}, \mathrm{Sc}, \mathrm{Sm}, \mathrm{Sr} \\
\mathrm{Yb}, \mathrm{Zn}\end{array}$ & Field conditions & Leaf & NAA & $\begin{array}{l}\text { Determining } \\
\text { essential and } \\
\text { toxic elements }\end{array}$ & [213] \\
\hline $\begin{array}{c}\text { Tobacco } \\
\text { (N. angsdorffii) }\end{array}$ & $\begin{array}{c}29 \text { elements } \\
\mathrm{Ba}, \mathrm{Bi}, \mathrm{Ca}^{2+}, \mathrm{Cd}, \mathrm{Co}, \mathrm{Cr}, \\
\mathrm{Cu}, \mathrm{Eu}, \mathrm{Fe}, \mathrm{Ga}, \mathrm{K}, \mathrm{Li}, \\
\mathrm{Mg}, \mathrm{Mn}, \mathrm{Mo}, \mathrm{Na}^{+}, \mathrm{P}, \mathrm{Pb}, \\
\mathrm{Pt}, \mathrm{Rb}, \mathrm{S}, \mathrm{Sb}, \mathrm{Sn}, \mathrm{Sr}, \mathrm{Te} \\
\text { V, W, Y, and } \mathrm{Zn}\end{array}$ & Agar medium & Root, stem and leaves & ICP-AES/MS & $\begin{array}{l}\text { Ionomic profiling } \\
\text { of } N \text {. langsdorffii } \\
\text { wild-type and } \\
\text { mutant genotypes } \\
\text { exposed to abiotic } \\
\text { stresses }\end{array}$ & [188] \\
\hline $\begin{array}{c}\text { Soybean } \\
\text { (Glycine soja (L.) } \\
\text { Merr. and G. } \\
\text { max) }\end{array}$ & $\mathrm{Br}, \mathrm{Cl}$, and $\mathrm{I}$ & Soil & Seeds & ICP-MS & $\begin{array}{l}\text { Determination of } \\
\text { bromine, chlorine, } \\
\text { and iodine in } \\
\text { soybean }\end{array}$ & [214] \\
\hline A. halleri & $\mathrm{Zn}, \mathrm{Cd}$ & Pot conditions & Leaf & $\begin{array}{l}\text { HPLC, } \\
\text { ICP-AES }\end{array}$ & $\begin{array}{l}\text { To investigate the } \\
\text { effects of the } \\
\text { heavy metals Zn } \\
\text { and/or Cd on } \\
\text { aphid in A. halleri }\end{array}$ & [125] \\
\hline A. thaliana & $\mathrm{Zn}$ & Growth chamber & Leaf tissue & LC-MS/MS & $\begin{array}{l}\text { Role in plant } \\
\text { immunity }\end{array}$ & [127] \\
\hline $\begin{array}{l}\text { Wheat } \\
\text { (T. aestivum) }\end{array}$ & $\mathrm{Zn}$ & Pot conditions & Seedlings & HPLC-MS & $\begin{array}{l}\text { key in the } \\
\text { R-gene-specific } \\
\text { resistance of } \\
\text { plants to } \\
\text { pathogens }\end{array}$ & [129] \\
\hline $\begin{array}{l}\text { Soybean } \\
\text { (G. soja) }\end{array}$ & $\mathrm{Na}^{+}, \mathrm{K} \mathrm{Ca}^{2+}$, and $\mathrm{Mg}$ & Field & $\begin{array}{l}\text { Roots, shoots, leaves, } \\
\text { seeds, and capsules }\end{array}$ & AAS & $\begin{array}{l}\text { The K-Na ratio of } \\
\text { seed, leaf, shoot, } \\
\text { and capsule were } \\
\text { all }>1 \text { in the wild }\end{array}$ & [215] \\
\hline $\begin{array}{c}\text { Lotus } \\
\text { Extremophile } \\
\text { (Lotus creticus) } \\
\text { and glycophytic } \\
\text { (Lotus } \\
\text { corniculatus and } \\
\text { Lotus tenuis. L.) }\end{array}$ & $\begin{array}{c}\mathrm{Ca}^{2+}, \mathrm{B}, \mathrm{P}, \mathrm{Mn}, \mathrm{S}, \mathrm{Zn}, \\
\mathrm{Mg}, \mathrm{Fe}, \mathrm{Cl}, \mathrm{K}, \mathrm{Na}^{+} \\
\text {(elements) } \\
\text { Proline, serine, sucrose, } \\
\text { Glyceric acid, citric acid, } \\
\text { succinic acid, erythronic } \\
\text { acid } \\
\text { (metabolites) }\end{array}$ & $\begin{array}{l}\text { Pot and filed } \\
\text { conditions }\end{array}$ & $\begin{array}{l}\text { Complete shoots } \\
\text { (pooling leaves, } \\
\text { petioles, and stems) }\end{array}$ & $\begin{array}{l}\text { Gas chromatog- } \\
\text { raphy coupled } \\
\text { to electron } \\
\text { impact } \\
\text { ionization-time } \\
\text { of flight-mass } \\
\text { spectrometry } \\
\text { (GC/EI-TOF- } \\
\text { MS) }\end{array}$ & $\begin{array}{l}\text { Glyphocites } \\
\text { adapted well } \\
\text { under salinity }\end{array}$ & [216] \\
\hline
\end{tabular}


Table 4. Cont.

\begin{tabular}{|c|c|c|c|c|c|c|}
\hline Plant species & Ion & Medium & Tissue Used & Platform & Study & Reference \\
\hline $\begin{array}{l}\text { Soybean } \\
\text { (G. max) }\end{array}$ & $\begin{array}{c}\mathrm{B}, \mathrm{Na}^{+}, \mathrm{Mg}, \mathrm{Al}, \mathrm{P}, \mathrm{S}, \mathrm{K} \\
\mathrm{Ca}^{2+}, \mathrm{Mn}, \mathrm{Fe}, \mathrm{Co}, \mathrm{Ni} \\
\mathrm{Cu}, \mathrm{Zn}, \mathrm{As}, \mathrm{Se}, \mathrm{Rb}, \mathrm{Mo} \\
\text { and } \mathrm{Cd}\end{array}$ & Filed conditions & Seeds & ICP-MS & $\begin{array}{c}\text { Ionomic } \\
\text { screening for } \\
\text { identifying } \\
\text { mutant soybean } \\
\text { lines with altered } \\
\text { elemental } \\
\text { composition }\end{array}$ & [18] \\
\hline $\begin{array}{l}\text { Soybean } \\
\text { (G. max) }\end{array}$ & $\begin{array}{c}\mathrm{B}, \mathrm{Al}, \mathrm{Mn}, \mathrm{Fe}, \mathrm{Co}, \mathrm{Ni}, \\
\mathrm{Cu}, \mathrm{Zn}, \mathrm{Sr}, \mathrm{Mo} \text {, and } \mathrm{Ba} \text {, }\end{array}$ & Soil & Seeds & $\begin{array}{l}\text { ICP-MS and } \\
\text { NMR }\end{array}$ & $\begin{array}{l}\text { Elemental and } \\
\text { lipid profiling of } \\
\text { transgenic } \\
\text { (cp4-EPSPS gene) } \\
\text { and wild type } \\
\text { soybean seed } \\
\text { generations }\end{array}$ & [217] \\
\hline $\begin{array}{c}\text { Acacia catechu, } \\
\text { Argemone } \\
\text { mexicana, Aegle } \\
\text { marmelos, } \\
\text { Datura metel, } \\
\text { Phyllanthus } \\
\text { emblica, } \\
\text { Sapindus } \\
\text { emarginatus, } \\
\text { Senna } \\
\text { occidentalis }\end{array}$ & $\begin{array}{c}13 \\
\text { elements } \\
\text { Major elements found: } \\
\mathrm{K}, \mathrm{Ca}^{2+}, \mathrm{Cl}, \mathrm{S}, \mathrm{P} \\
\text { Lower elements: } \mathrm{Cu}, \mathrm{Zn} \text {, } \\
\mathrm{Fe}, \mathrm{Mn}, \mathrm{Se}, \mathrm{Br}, \mathrm{Rb}, \mathrm{Sr}\end{array}$ & $\begin{array}{l}\text { Field } \\
\text { conditions }\end{array}$ & Leaves, bark, fruits & XRF & Phytomedicine & [218] \\
\hline
\end{tabular}

Dragut et al. [219] developed an ionomics Atlas connecting the leaf ionome of an $A$. thaliana population, with respect to their landscape distribution. This ionomics Atlas consists of elemental data, the HapMap collection of 348 accessions of associated genetic loci, and properties of the habitat, such as geo-location and climate data (pressure, temperature, soil properties, humidity, and precipitation), where the accessions were collected, and can be accessed via iHUB. The ionomics Atlas helps researchers investigate the association of ionomics, genomic, and environmental data using the Google Maps application. Such tools enable the exploration of the possible role of natural ionomic variation in the landscape. In addition to data on $A$. thaliana, the iHUB contains ionomics data of economically important crops such as maize, rice, and soybean $[219,220]$, and the eukaryotic model organism yeast [221]. Further, the iHUB tool can be used to study gene function and predict potential mutants for further analysis. As the amount of data produced by ionomics studies grows exponentially, visual interfaces and management systems for high-throughput ionomics data collection, storage, retrieval, and validation, and bioinformatics tools for data analysis, are becoming increasingly important. Furthermore, new ionome-based classification and prediction models need to be developed using machine learning algorithms and artificial neural networks (ANNs) to provide vital indicators for the early detection of stresses in sustainable agriculture. The procedure for analyzing and processing ionome data from various plant tissues under different environmental conditions using high-throughput platforms is shown in Figure 3. 


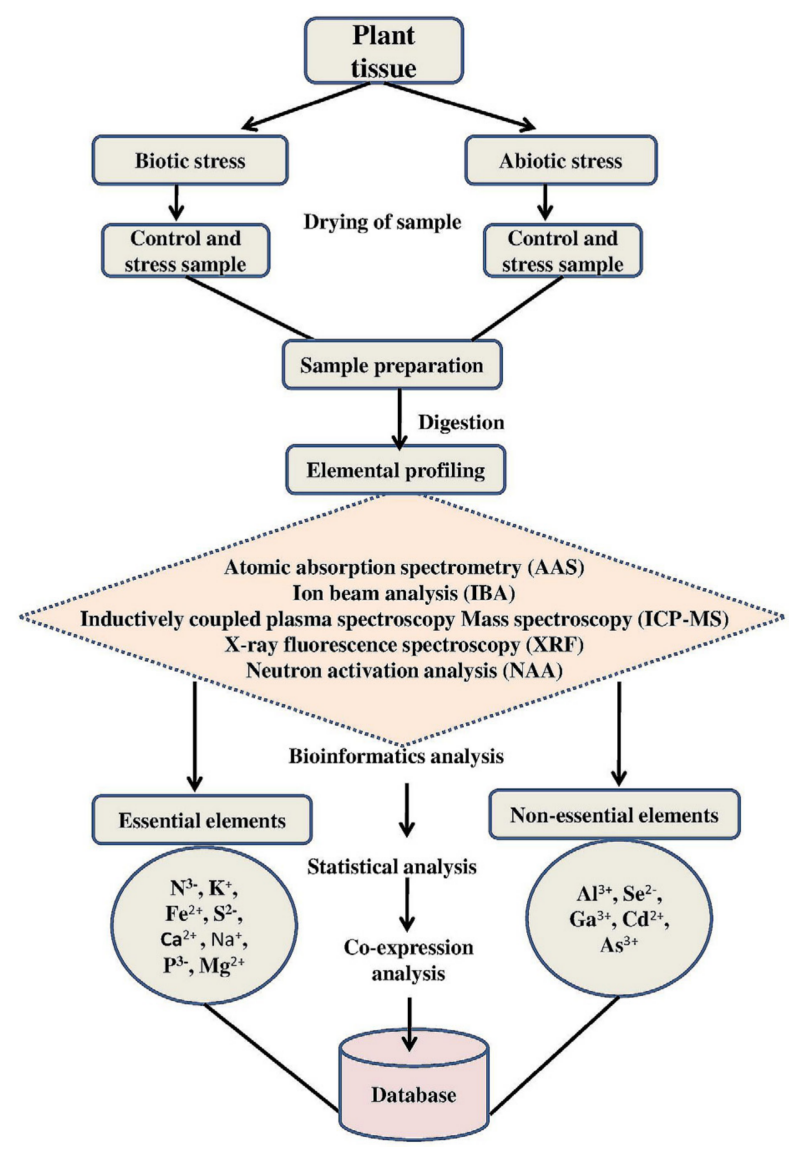

Figure 3. Description of ionomics workflow in plants under control and stress conditions. Sample preparation and elemental profiling using various analytical instruments is emphasized. The role of bioinformatics and other statistical methods to interpret ionomics data that can be stored in a database for future research is also highlighted.

\section{Transporters and Channels Involved in Elemental Uptake and Transport}

Plant nutrient contents are controlled by the balanced activities of membrane transporters that mediate nutrient uptake and distribution in order to maintain relative compositional homeostasis [222]. Ion accumulation is an intricate process that influences almost every stage of plant growth, as well as plant development and survival. The most important function of plant roots is sensing and absorption of nutrients, as well as essential mineral molecules, from the soil in order to sustain the growth and development of the plant. Many transporters, belonging to different transporter groups, mediate mineral uptake [223]. Herein, we discuss some of the important ion transporters and their regulation during various stress conditions.

Plants essentially require various metal ions such as $\mathrm{Fe}, \mathrm{Co}, \mathrm{Zn}, \mathrm{Cu}, \mathrm{Ni}$, and $\mathrm{Mn}$ for growth and metabolic processes. The transport and accumulation of these metal ions in plants must be strictly regulated as excess ions can be deleterious to plant health. The accumulated metals are transported by specific transporters to various locations of the plant cell [224]. The major transporter proteins that are responsible for this process are heavy metal ATPases (HMAs), the natural resistance-associated macrophage protein (Nramp) family, the cation diffusion facilitator (CDF) family, the zinc-iron permease (ZIP) family, and the multidrug and toxin efflux (MATE) protein family and ATP-binding cassette (ABC) transporters [41]. HMAs are essential metal-transporting proteins that use ATP to pump transition metals such as $\mathrm{Cu}, \mathrm{Cd}, \mathrm{Zn}, \mathrm{Co}$, and $\mathrm{Pb}$ across the membranes. The heavy metal ATPases have two subclasses: CPx-type and P1B-type. The CPx-type ATPases are accountable for the transport of $\mathrm{Cd}, \mathrm{Zn}, \mathrm{Pb}$, and $\mathrm{Cu}$ through the cell membranes [225], whereas P1B-type ATPases are responsible for regulating homeostasis and tolerance to metal ac- 
cumulation, in addition to metal transport [226]. These HMAs, when overexpressed in various organs of plants, cause an increase in the accumulation of metals [227]. In terms of phylogeny, HMAs belongs to two major classes: the first class is $\mathrm{Cu} / \mathrm{Ag}$, and the other is $\mathrm{Zn} / \mathrm{Co} / \mathrm{Cd} / \mathrm{Pb}$ [226]. In the case of plants, there are 8 and 9 copies of HMA genes in $O$. sativa and A. thaliana, respectively. The AtHMA1 member of the first group is a chloroplastic protein that detoxifies $\mathrm{Zn}$ [228]. The AtHMA1 deletion mutant is characterized by an inability to resist high $\mathrm{Zn}$ concentrations. Another member of this group, AtHMA3, is embedded in vacuoles and aids in the removal of $\mathrm{Zn}$ and $\mathrm{Cd}[229,230]$. Additionally, it is also known to cause variability in the root and shoot tissues of various Arabidopsis species that overexpress AtHMA3 and hence accumulate higher levels of $\mathrm{Cd}$ [121]. The AtHMA2 and AtHMA4 genes are embedded in the cell membrane and play a vital role in $\mathrm{Cd}$ and $\mathrm{Zn}$ detoxification [231-234]. Unlike dicots, there are few studies on HMAs from monocots. In rice, nine HMAs (OsHMA1, OsHMA2, OsHMA3, OsHMA4, OsHMA5, OsHMA6, OsHMA7, OsHMA8, and OsHMA9) were identified based on the genome sequence analysis [229]. OsHMA1 shares $71 \%$ identity with AtHMA1 and shows differential expression in rice plants under Zn-deficient and Zn-rich conditions, implying that it may be involved in $\mathrm{Zn}$ detoxification [235]. Previous studies have shown that OsHMA2 is localized to the plasma membrane and is involved in the transport of Cd and Zn [236]. Similarly, OsHMA3 was found to control of root-to-shoot Cd translocation rates [237]. In rice, OsHMA4-OsHMA9 belongs to $\mathrm{Cu} / \mathrm{Ag}$ subgroup of HMAs. Out of them, OsHMA4 functions to sequester $\mathrm{Cu}$ into root vacuoles, limiting $\mathrm{Cu}$ accumulation in the grains [43]. Similarly, rice under high $\mathrm{Cu}$ concentrations highly expresses OsHMA5, hence might play a key role in $\mathrm{Cu}$ detoxification [238]. In addition, based on genome sequence analysis, 11 HMAs in maize and sorghum have been identified and are grouped according to the Arabidopsis and rice HMAs [239].

The second major metal transport protein family is the Nramp family. This family is present in diverse organisms ranging from simple-celled organisms such as bacteria to complex eukaryotes such as plants, animals, and fungi. In plants, the Nramp family was first identified in rice, which has three of these genes, followed by Arabidopsis, which has six copies $[225,240]$. Plants that encode NRAMP (natural resistance-associated macrophage protein) genes have been classified into two sub-families. The first group encodes AtNramps 1 and 6, whereas the second encodes AtNRAMPs 2-5 [240,241]. OsNramps 1 and 3 of rice fall in the first group, whereas OsNRAMP 2 falls in the second group of the NRAMP family. CDFs are intermembrane transporters found in all living organisms which serve a vital role in the homeostasis of divalent metal cations including $\mathrm{Zn}^{2+}, \mathrm{Fe}^{2+}$, $\mathrm{Cd}^{2+}, \mathrm{Co}^{2+}, \mathrm{Ni}^{2+}, \mathrm{Mn}^{2+}$, and possibly $\mathrm{Cu}^{2+}$ and $\mathrm{Pb}^{2+}$. They have a transmembrane domain (TMD) and a cytoplasmic C-terminal domain (CTD) [242]. Plant CDFs are commonly called MTPs (Metal Tolerance Proteins) and have primarily been characterized as $\mathrm{Mn}^{2+}$ transport proteins. CDFs are divided into three types based on their metal ion selectivity. (i) Mn-CDF with $\mathrm{Mn}^{2+}$ as the only substrate (ii) $\mathrm{Fe} / \mathrm{Zn} \mathrm{CDF}$ with the $\mathrm{Fe}^{2+}$ and $\mathrm{Zn}^{2+}$ as well as other metal ions as substrates (iii) $\mathrm{Zn}-\mathrm{CDF}$ with $\mathrm{Zn}^{2+}$ and other metal ions as substrates but not $\mathrm{Fe}^{2+}$ or $\mathrm{Mn}^{2+}$ [243]. As their role is primarily focused on effluxing, these transporters are also known as "cation efflux transporters" [244].

On the other hand, ZIP is a well-known transporter family that was first identified in plants and is competent of transporting an array of cations, including $\mathrm{Fe}, \mathrm{Zn}, \mathrm{Cd}$, and Mn [244]. They are present in a variety of cell organelles and play an important role in both $\mathrm{Zn}$ homeostasis and plant adaptation to low and high Zn soils [245]. In addition, ZIP transporters also play a key role in Zn biofortification of grains. Interestingly, ZIP family transporter genes have been identified in many crops but are mainly validated in Arabidopsis (AtZIP1, AtZIP2, AtZIP3, and AtZIP4) [240,246] and rice plants (OsZIP1, OsZIP3, OsZIP4, OsZIP5, OsZIP7, and OsZIP8) [247]. MATE membrane effluxers are a primitive gene family of secondary transporters present in all living organisms but with a particularly large presence in plants. They play a key role in plant resistance to $\mathrm{Al}$ toxicity by inducing citrate efflux [248]. They also play a role in nutrient homeostasis in plants, such 
as $\mathrm{Fe}^{3+}$ uptake as well as the transport of secondary metabolites and hormones. Various MATE transporter genes have been identified in both model and crop plants like 56 in Arabidopsis [249], 117 in G. max [250], 70 in M. truncatula [251], and 45 in O. sativa [249]. Previously it was found that MATE transporter genes were upregulated in rice plants during Cd stress, suggesting that they could be involved in Cd detoxification [252]. Since MATE transporters play important roles in plant physiological processes, they may be good candidates for plant breeding programs aimed at improving agricultural traits like aluminum resistance, iron nutrition, and secondary metabolite accumulation [248].

$\mathrm{ABC}$ transporters comprise large group proteins that are found in microorganisms, plants, and animals [253]. Approximately 120 ABC transporter members in Arabidopsis and rice have been identified; they are grouped into seven subfamilies [254]. They are involved in diverse functions such as the transport of various molecules, including ions, lipids, carbohydrates, phytohormones, and heavy metals, across the cell membrane as well as across various cell organelles [240]. The ABC transporters are known to regulate several physiological processes such as transpiration, stomatal conductance, respiration, and photosynthesis in plants [255]. In addition to transporting various molecules, these transporters are known to transport various metals such as $\mathrm{Cd}$, and thus, play a defensive role against heavy metal stress [256]. In plants, $\mathrm{Cd}$ is extremely toxic and can lead to nutrient homeostasis disturbance, DNA and membrane damage, protein dysfunction, and generation of noxious reactive oxygen species (ROS), all of which can lead to a substantial reduction in crop growth and productivity [257]. Overexpression of AtABCC1 improves $\mathrm{Cd}$ tolerance and accumulation in Arabidopsis, whereas its knockout makes plants more vulnerable to Cd stress [258]. It is also known to detoxify $\mathrm{Al}$ in plants [259]. Hence, using ionomics tools, the role of different $\mathrm{ABC}$ transporters in mitigating heavy metal stresses in economically important crops can be further investigated.

As metalloids are both beneficial and toxic to plants, their precise regulation of uptake and translocation is crucial. Most metalloids are transported by aquaporins (AQPs), among which nodulin 26-like intrinsic protein-III (NIP-III), which belongs to the AQP family, has been found to be associated with the transportation of metalloids such as $\mathrm{Si}$, $\mathrm{B}, \mathrm{Ge}$, and As $[165,260]$. NIP-IIIs are passive channels that facilitate the transportation of metalloids from the soil to roots. However, another class of transporter proteins, the arsenite-antimonite (arsb) efflux family, is involved in metalloid transport from the root to shoot [261,262]. The arsb family, also known as the Lsi2 (low silicon 2) family, comprises active efflux transporter proteins. As soon as NIP-IIIs take up Si from the soil within root cells, Lsi2 transports Si outside the cortical cells toward the stele. Once Si reaches the stele, it is further transported to areal tissues via xylem flow. NIP-IIIs and Lsi2s have been found in several plant species such as barley [263], soybean [264], maize [265], and wheat [266]. Ionomics tools such as ICP-MS and pXRF significantly help in the identification of loci and genes that govern the metalloid transportation process in plants [261,264]. Metalloids such as $\mathrm{Si}$ and $\mathrm{B}$ are known to enhance tolerance against several abiotic stresses. In particular, $\mathrm{Si}$ imparts resilience to plant species under biotic and abiotic stress conditions [166]. Several efforts have been made toward genome-wide identification of AQPs and their subsequent characterization into sub-classes, including metalloid transporter NIP-IIIs [165,201]. These studies have extensively used transcriptomics and genomics resources, but minimal information about ionomics has been integrated. Hence, using ionomics, it can be determined whether these transporters will take up other metalloids from the soil; this will provide novel insights for crop improvement.

\section{Ionomics and Integrated Omics Approaches}

Multi-omics, along with other high-throughput tools, has revolutionized plant biology as it provides real-time readouts of hundreds of genes, proteins, metabolites, and ions at various developmental stages and under different environmental conditions. It possesses great potential to improve the nutritional status, as well as biotic and abiotic stress resilience, of plants. Although genomic tools can predict genes, genetic products 
such as proteins, metabolites, and ions can differ significantly due to transcriptional and post-transcriptional modifications. Hence, multi-omics will enable a better understanding of the metabolic networks, gene functions, and biochemical pathways, as well as their associations [214]. "Ionome", "proteome", "transcriptome", and "metabolome" are four distinct terms that are interdependent and have overlapping boundaries [267]. These approaches produce a complex system of elements governed by the plant's physiological and biochemical characteristics, which are in turn governed by the genome. In living systems, all processes are interconnected and equally important for the normal functioning of cells. In this regard, information derived from different omics approaches can help establish the inter-dependency of different cellular components, to draw a better picture of molecular phenomena [132,163]. To reconstruct complex networks that describe phenotypes in cells, ionomic profiling needs to be integrated with multiple omics data (Figure 4). A typical problem with ionomics data is a disparity in the correlated ions for their association with a biological function. To understand the complexity of a biochemical mechanism in cellular metabolism, as well as its regulation, a combination of transcriptomics data and metabolomic correlations is a suitable approach. Using publicly accessible data, further construction of gene-to-metabolite networks can be performed using in silico analysis of genes and metabolites. Multi-omics, in combination with high-throughput DNA sequencing, has allowed active investigations of networks that regulate biotic and abiotic stress responses, as well as studies on trait variation in different crop species [132,163,268].

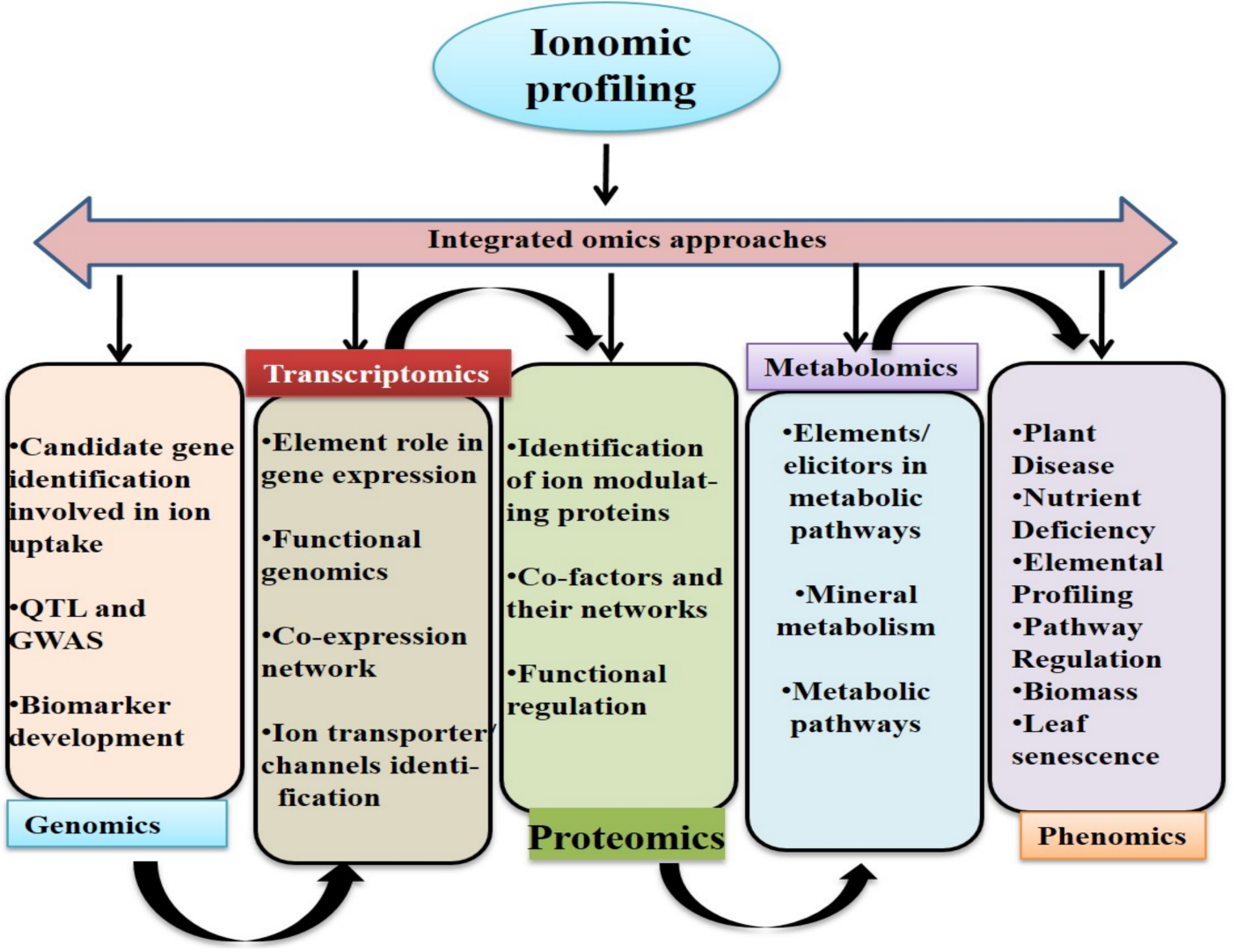

Figure 4. Ionomics and its integration with other omics approaches for identifying stress-resilient genes. Integration of multi-omics approaches provides the overall picture of the information flow from the upstream step of central dogma (genomics) to the last downstream level (metabolomics) that can define the phenotype. All omics are interdependent; hence, their integration will possibly allow the identification of potential genes and their regulatory networks, which can be used for developing smart crops for sustainable agriculture via genome editing or molecular breeding.

A number of omics-based approaches, including ionomics, have been exploited in both model (Arabidopsis) and crop plants (wheat, rice, and tomato) to understand the underly- 
ing complexity of plant stress biology [269-275]. Ionomics and its integration with other omics have shown how organic $\mathrm{N}$ increases agricultural crop yield in an agroecosystem. This study highlights the importance of soil solarisation (SS) mediated increased growth response in Brassica rapa and it was found that SS boosted plant shoot biomass regardless of the type of fertilizer used. Further, using a multiomics approach, they identified soil organic $\mathrm{N}$ which is induced by soil solarization as one of the key components to increase crop yield in B. rapa. [276]. Another multi-omics approach shed light on combined yieldrelated traits and enhanced abiotic stress tolerance in tobacco [277]. Recently, ionomics and metabolomics studies revealed the role of $\mathrm{P}$ in wheat plants in improving drought stress tolerance [278]. Based on their findings, T. aestivum plants in the low phosphorus (LP) treatment were more drought tolerant than those in the conventional phosphorus (CP) treatment, which is likely due to the presence of a comprehensive mobilization of sugar metabolism, that regulates osmotic balance, as well as the accumulation of various organic acids, or the regulation of intracellular ion homeostasis. Interestingly, they also found the impact of different $\mathrm{P}$ supply on elements. Viz., $\mathrm{K}, \mathrm{Ca}^{2+}, \mathrm{P}, \mathrm{Si}, \mathrm{Na}^{+}, \mathrm{Mn}, \mathrm{Mg}$, and $\mathrm{Zn}$ which were differently regulated in presence of $\mathrm{LP}$ and $\mathrm{CP}$ treated plants during drought stress [278]. Subsequently, a variety of omics techniques has been successfully employed to better understand the genetic processes that regulate the plant ionome [279]. Guo et al. [280] provided an insight into the ionomics and transcriptomics of two cotton genotypes (sensitive and tolerant) under salinity stress. They found that the concentrations of $\mathrm{Na}^{+}$in the roots, stems, and leaves increased significantly, whereas those of $\mathrm{K}, \mathrm{Cu}, \mathrm{B}$, and Mo in the roots, as well as those of $\mathrm{Mg}$ and $\mathrm{S}$ in the leaves, decreased significantly under stress. Based on the ionomic profiling it was found that salt-sensitive cotton cultivar had more ions ( $\mathrm{Fe}, \mathrm{Mn}, \mathrm{Zn}, \mathrm{S}, \mathrm{K}, \mathrm{Ca}^{2+}$, and $\mathrm{P}$ ) that were negatively related to $\mathrm{Na}^{+}$than the salttolerant cultivar, respectively. Similarly, ionomic and metabolic profiling of maize seedlings carried out during neutral and alkaline salt stress has provided abundance information on the role of ions and metabolites [281]. Furthermore, integrated multi-omics analysis of barley root zones revealed two distinctive salt tolerant pathways based on the salt induced lignin and suberin impregnation in the root cells [282]. Grobikinsky et al. [283] studied the complicated molecular mechanisms of leaf senescence in model and non-model plant species using a multi-omics approach. Various efforts have been made to understand stress tolerance in tomato, soybean, brassica, barley, maize, wheat, and Arabidopsis using integrative omics-based approaches $[132,163,193,279,284]$. The impact of omics has provided an excellent platform to understand the pathways that regulate tolerance in grapevine upon exposure to both biotic and abiotic stress [285]. Ionomics and its integration with other omics approaches have been instrumental in elucidating the molecular complexity of plant stress biology and identifying target genes for developing smart crops for sustainable agriculture (Figure 4).

\section{Conclusions}

In the last decade, ionomics has grown in popularity as a high-throughput tool for studying the metabolism and homeostasis of ions or elements in a variety of species, including plants and animals. However, knowledge of the relationship between different ions or minerals and different stresses is limited. Being sessile, plants face numerous biotic and abiotic stresses, leading to negative effects on their growth, yield, and sustainable agricultural production. In this regard, many mineral nutrients, namely, N, P, K, S, Mg, Zn, $\mathrm{Fe}, \mathrm{Se}$, and $\mathrm{Si}$, play a positive role in mitigating biotic and abiotic stresses. Traditionally, plant mineral analysis is performed manually and is expensive, time-consuming, less precise, and less reliable. However, the emergence of ionomics involving high-throughput elemental profiling of mineral nutrients and trace elements using various spectroscopic techniques has considerably increased the throughput and precision, as well as reduced the cost, of mineral analysis of crop plants. Owing to progressions in analytical tools and techniques, ionomics has emerged as a potentially favorable approach for sustainable crop improvement. Ionomics has successfully enabled the discovery of crucial genes, as well as 
the pathways, responsible for regulating mineral nutrient and trace element concentrations in the plant to present biotic and abiotic stress tolerance. These genes can be used to create smart crops with high nutritive value and greater resistance to environmental stresses through genome editing or molecular breeding. Ionomics has been proven to be a crucial method for the discovery of the loci that control ionomic variation naturally. Moreover, the current progress in "omics" approaches and strategies for their integration will lead to the creation of a novel genomic resource for developing economically important and stress-resistant crops for sustainable agriculture. In conclusion, the integration of omics with current breeding programs can lead to an evolution from genome-assisted breeding $(\mathrm{GAB})$ to omics-assisted breeding $(\mathrm{OAB})$ in future studies.

Author Contributions: Conceptualization, H.B. and S.A.; writing-original draft preparation, S.A.; review and editing, A.T. and H.B.; visualization A.T., supervision, H.B.; project administration, H.B.; funding acquisition, H.B. All authors have read and agreed to the published version of the manuscript.

Funding: This research was carried out with the support of the Forest Science and Technology project (Project No. 2019147B10-2121-AB02) provided by Korea Forest service.

Conflicts of Interest: The authors declare no conflict of interest.

\section{References}

1. Atkinson, N.J.; Urwin, P.E. The interaction of plant biotic and abiotic stresses: From genes to the field. J. Exp. Bot. 2012, 63, 3523-3543. [CrossRef] [PubMed]

2. Suzuki, N.; Rivero, R.M.; Shulaev, V.; Blumwald, E.; Mittler, R. Abiotic and Biotic Stress Combinations. New Phytol. 2014, 203, 32-43. [CrossRef] [PubMed]

3. He, M.; He, C.Q.; Ding, N.Z. Abiotic Stresses: General Defenses of Land Plants and Chances for Engineering Multistress Tolerance. Front. Plant Sci. 2018, 1771. [CrossRef] [PubMed]

4. Ali, S.; Mir, Z.A.; Tyagi, A.; Bhat, J.A.; Chandrashekar, N.; Papolu, P.K.; Rawat, S.; Grover, A. Identification and comparative analysis of Brassica juncea pathogenesis-related genes in response to hormonal, biotic and abiotic stresses. Acta Physiol. Plant. 2017, 39, 268. [CrossRef]

5. Pandey, A.; Ramegowda, V.; Senthil-Kumar, M. Shared and Unique Responses of Plants to Multiple Individual Stresses and Stress Combinations: Physiological and Molecular Mechanisms. Front. Plant Sci. 2015, 723. [CrossRef]

6. Raza, A.; Razzaq, A.; Mehmood, S.S.; Zou, X.; Zhang, X.; Lv, Y.; Xu, J. Impact of Climate Change on Crops Adaptation and Strategies to Tackle Its Outcome: A Review. Plants 2019, 8, 34. [CrossRef]

7. Muszyńska, E.; Labudda, M. Dual Role of Metallic Trace Elements in Stress Biology—From Negative to Beneficial Impact on Plants. Int. J. Mol. Sci. 2019, 20, 3117. [CrossRef]

8. Campos, A.C.A.L.; Kruijer, W.; Alexander, R.; Akkers, R.C.; Danku, J.; Salt, D.E.; Aarts, M.G.M. Natural variation in Arabidopsis thaliana reveals shoot ionome, biomass, and gene expression changes as biomarkers for zinc deficiency tolerance. J. Exp. Bot. 2017, 68, 3643-3656. [CrossRef]

9. Maathuis, F.J. Physiological Functions of Mineral Macronutrients. Curr. Opin. Plant Biol. 2009, 12, 250-258. [CrossRef]

10. Williams, L.; Salt, D.E. The Plant Ionome Coming into Focus. Curr. Opin. Plant Biol. 2009, 12, 247-249. [CrossRef]

11. Watanabe, T.; Urayama, M.; Shinano, T.; Okada, R.; Osaki, M. Application of Ionomics to Plant and Soil in Fields under Long-Term Fertilizer Trials. SpringerPlus 2015, 4, 781. [CrossRef]

12. Fattorini, L.; Ronzan, M.; Piacentini, D.; Della Rovere, F.; de Virgilio, C.; Sofo, A.; Altamura, M.M.; Falasca, G. Cadmium and Arsenic Affect Quiescent Centre Formation and Maintenance in Arabidopsis thaliana Post-Embryonic Roots Disrupting Auxin Biosynthesis and Transport. Environ. Exp. Bot. 2017, 144, 37-48. [CrossRef]

13. Shahid, M.; Khalid, S.; Abbas, G.; Shahid, N.; Nadeem, M.; Sabir, M.; Aslam, M.; Dumat, C. Heavy Metal Stress and Crop Productivity. In Crop Production and Global Environmental Issues; Springer: Cham, Switzerland, 2015; pp. 1-25.

14. Salt, D.E.; Baxter, I.; Lahner, B. Ionomics and the Study of the Plant Ionome. Annu. Rev. Plant. Biol. 2008, 59, 709-733. [CrossRef]

15. Pita-Barbosa, A.; Ricachenevsky, F.K.; Wilson, M.; Dottorini, T.; Salt, D.E. Transcriptional Plasticity Buffers Genetic Variation in Zinc Homeostasis. Sci. Rep. 2019, 9, 19482. [CrossRef]

16. Lahner, B.; Gong, J.; Mahmoudian, M.; Smith, E.L.; Abid, K.B.; Rogers, E.E.; Guerinot, M.L.; Harper, J.F.; Ward, J.M.; McIntyre, L.; et al. Genomic Scale Profiling of Nutrient and Trace Elements in Arabidopsis thaliana. Nat. Biotechnol. 2003, 21, 1215-1221. [CrossRef]

17. Danku, J.M.C.; Lahner, B.; Yakubova, E.; Salt, D.E. Large-Scale Plant Ionomics. Methods Mol. Biol. 2013, 953, 255-276.

18. Ziegler, G.; Terauchi, A.; Becker, A.; Armstrong, P.; Hudson, K.; Baxter, I. Ionomic Screening of Field-Grown Soybean Identifies Mutants with Altered Seed Elemental Composition. Plant Genome 2013, 6. [CrossRef] 
19. Baxter, I.R.; Ziegler, G.; Lahner, B.; Mickelbart, M.V.; Foley, R.; Danku, J.; Armstrong, P.; Salt, D.E.; Hoekenga, O.A. Single-Kernel Ionomic Profiles Are Highly Heritable Indicators of Genetic and Environmental Influences on Elemental Accumulation in Maize Grain (Zea mays). PLoS ONE 2014, 9, e87628. [CrossRef]

20. Pinson, S.R.M.; Tarpley, L.; Yan, W.; Yeater, K.; Lahner, B.; Yakubova, E.; Huang, X.-Y.; Zhang, M.; Guerinot, M.L.; Salt, D.E.; et al. Worldwide Genetic Diversity for Mineral Element Concentrations in Rice Grain. Crop Sci. 2015, 55, 294-311. [CrossRef]

21. Thomas, C.L.; Alcock, T.D.; Graham, N.S.; Hayden, R.; Matterson, S.; Wilson, L.; Young, S.D.; Dupuy, L.X.; White, P.J.; Hammond, J.P.; et al. Root Morphology and Seed and Leaf Ionomic Traits in a Brassica Napus L: Diversity Panel Show Wide Phenotypic Variation and Are Characteristic of Crop Habit. BMC Plant Biol. 2016, 16, 214. [CrossRef]

22. D’Attoma, G.; Morelli, M.; Saldarelli, P.; Saponari, M.; Giampetruzzi, A.; Boscia, D.; Savino, V.N.; la Fuente, L.D.; Cobine, P.A. Ionomic Differences between Susceptible and Resistant Olive Cultivars Infected by Xylella Fastidiosa in the Outbreak Area of Salento, Italy. Pathogens 2019, 8, 272. [CrossRef]

23. Cesco, S.; Tolotti, A.; Nadalini, S.; Rizzi, S.; Valentinuzzi, F.; Mimmo, T.; Porfido, C.; Allegretta, I.; Giovannini, O.; Perazzolli, M.; et al. Plasmopara Viticola Infection Affects Mineral Elements Allocation and Distribution in Vitis Vinifera Leaves. Sci. Rep. 2020, 10, 18759. [CrossRef] [PubMed]

24. Baxter, I.R.; Vitek, O.; Lahner, B.; Muthukumar, B.; Borghi, M.; Morrissey, J.; Guerinot, M.L.; Salt, D.E. The Leaf Ionome as a Multivariable System to Detect a Plant's Physiological Status. Proc. Natl. Acad. Sci. USA 2008, 105, 12081-12086. [CrossRef]

25. Chao, D.Y.; Baraniecka, P.; Danku, J.; Koprivova, A.; Lahner, B.; Luo, H.; Yakubova, E.; Dilkes, B.; Kopriva, S.; Salt, D.E. Variation in Sulfur and Selenium Accumulation Is Controlled by Naturally Occurring Isoforms of the Key Sulfur Assimilation Enzyme Adenosine 5'-Phosphosulfate Reductase2 across the Arabidopsis Species Range. Plant Physiol. 2014, 166, 1593-1608. [CrossRef]

26. White, P.J.; Broadley, M.R.; Thompson, J.A.; McNicol, J.W.; Crawley, M.J.; Poulton, P.R.; Johnston, A.E. Testing the Distinctness of Shoot Ionomes of Angiosperm Families Using the Rothamsted Park Grass Continuous Hay Experiment. New Phytol. 2012, 196, 101-109. [CrossRef]

27. Shakoor, N.; Ziegler, G.; Dilkes, B.P.; Brenton, Z.; Boyles, R.; Connolly, E.L.; Kresovich, S.; Baxter, I. Integration of Experiments across Diverse Environments Identifies the Genetic Determinants of Variation in Sorghum Bicolor Seed Element Composition. Plant Physiol. 2016, 170, 1989-1998. [CrossRef]

28. Kamiya, T.; Borghi, M.; Wang, P.; Danku, J.M.C.; Kalmbach, L.; Hosmani, P.S.; Naseer, S.; Fujiwara, T.; Geldner, N.; Salt, D.E. The MYB36 Transcription Factor Orchestrates Casparian Strip Formation. Proc. Natl. Acad. Sci. USA 2015, 112, 10533-10538. [CrossRef]

29. Hindt, M.N.; Akmakjian, G.Z.; Pivarski, K.L.; Punshon, T.; Baxter, I.; Salt, D.E.; Guerinot, M. Lou. BRUTUS and Its Paralogs, BTS LIKE1 and BTS LIKE2, Encode Important Negative Regulators of the Iron Deficiency Response in Arabidopsis thaliana. Metallomics 2017, 9, 876-890. [CrossRef]

30. Whitt, L.; Ricachenevsky, F.K.; Ziegler, G.Z.; Clemens, S.; Walker, E.; Maathuis, F.J.; Kear, P.; Baxter, I. A curated list of genes that affect the plant ionome. Plant Direct 2020, 4, e00272. [CrossRef]

31. Kisko, M.; Bouain, N.; Safi, A.; Medici, A.; Akkers, R.C.; Secco, D.; Fouret, G.; Krouk, G.; Aarts, M.G.M.; Busch, W.; et al. LPCAT1 controls phosphate homeostasis in a zinc-dependent manner. eLife 2018, 7, e32077. [CrossRef]

32. Barberon, M.; Dubeaux, G.; Kolb, C.; Isono, E.; Zelazny, E.; Vert, G. Polarization of IRON-REGULATED TRANSPORTER 1 (IRT1) to the plant-soil interface plays crucial role in metal homeostasis. Proc. Natl. Acad. Sci. USA 2014, 111, 8293-8298. [CrossRef] [PubMed]

33. Xu, J.; Shi, S.; Wang, L.; Tang, Z.; Lv, T.; Zhu, X.; Ding, X.; Wang, Y.; Zhao, F.J.; Zhongchang, W.U. OsHAC 4 Is critical for arsenate tolerance and regulates arsenic accumulation in rice. New Phytol. 2017, 215, 1090-1101. [CrossRef] [PubMed]

34. Li, H.; Miao, Y.U.; Xin-Qiao, D.U.; Wang, Z.F.; Wei-Hua, W.U.; Quintero, F.J.; Jin, X.H.; Li, H.D.; Wang, Y.I. NRT1.5/NPF7.3 functions as a proton-coupled $\mathrm{H}^{+} / \mathrm{K}^{+}$antiporter for $\mathrm{K}^{+}$loading into the xylem in arabidopsis. Plant Cell 2017, 29, $2016-2026$. [CrossRef]

35. Huang, X.-Y.; Chao, D.-Y.; Koprivova, A.; Danku, J.; Wirtz, M.; Müller, S.; Sandoval, F.J.; Bauwe, H.; Roje, S.; Dilkes, B.; et al. Nuclear localised More Sulphur Accumulation1 epigenetically regulates sulphur homeostasis in Arabidopsis thaliana. PLoS Genet. 2016, 12, e1006298. [CrossRef]

36. Yan, J.; Chia, J.-C.; Sheng, H.; Jung, H.-I.; Tetiana-Olena Zavodna, L.U.; Zhang, R.H.; Zavodna, T.O.; Zhang, L.; Huang, R.; Jiao, C.; et al. Arabidopsis pollen fertility requires the transcription factors CITF1 and SPL7 that regulate copper delivery to anthers and jasmonic acid synthesis. Plant Cell 2017, 29, 3012-3029. [CrossRef]

37. Olsen, L.I.; Hansen, T.H.; Larue, C.; Osterberg, J.T.; Hoffmann, R.D.; Liesche, J.; Kramer, U.; Surblé, S.; Cadarsi, S.; Samson, V.A.; et al. Mother-plant-mediated pumping of zinc into the developing seed. Nat. Plants 2016, 2, 16036. [CrossRef]

38. Zhu, J.; Lau, K.; Puschmann, R.; Harmel, R.K.; Zhang, Y.; Pries, V.; Gaugler, P.; Broger, L.; Dutta, A.K.; Jessen, H.J.; et al. Two bifunctional inositol pyrophosphate kinases/phosphatases control plant phosphate homeostasis. eLife 2019, 8, e43582. [CrossRef]

39. Lindsay, E.R.; Maathuis, F.J.M. Arabidopsis thaliana NIP7;1 is involved in tissue arsenic distribution and tolerance in response to arsenate. FEBS Lett. 2016, 590, 779-786. [CrossRef]

40. Ueno, D.; Sasaki, A.; Yamaji, N.; Miyaji, T.; Fujii, Y.; Takemoto, Y.; Moriyama, S.; Che, J.; Moriyama, Y.; Iwasaki, K.; et al. A polarly localized transporter for efficient manganese uptake in rice. Nat. Plants 2015, 1, 15170. [CrossRef]

41. Kobayashi, T.; Nagasaka, S.; Senoura, T.; Itai, R.N.; Nakanishi, H.; Nishizawa, N.K. Iron-binding haemerythrin RING ubiquitin ligases regulate plant iron responses and accumulation. Nat. Comm. 2013, 4, 2792. [CrossRef] 
42. Chen, Y.I.; Sun, S.-K.; Tang, Z.; Liu, G.; Moore, K.L.; Maathuis, F.J.M.; Miller, A.J.; McGrath, S.P.; Zhao, F.-J. The nodulin 26-like intrinsic membrane protein OsNIP3;2 is involved in arsenite uptake by lateral roots in rice. J. Exp. Bot. 2017, 68, 3007-3016. [CrossRef] [PubMed]

43. Huang, X.-Y.; Deng, F.; Yamaji, N.; Pinson, S.R.M.; Fujii-Kashino, M.; Danku, J.; Douglas, A.; Guerinot, M.L.; Salt, D.E.; Ma, J.F. A heavy metal P-Type ATPase OsHMA4 prevents copper accumulation in rice grain. Nat. Commun. 2016, 7, 12138. [CrossRef] [PubMed]

44. Huang, X.-Y.; Liu, H.; Zhu, Y.-F.; Pinson, S.R.M.; Lin, H.-X.; Guerinot, M.L.; Zhao, F.-J.; Salt, D.E. Natural variation in a molybdate transporter controls grain molybdenum concentration in rice. New Phytol. 2019, 221, 1983-1997. [CrossRef] [PubMed]

45. Sun, S.-K.; Chen, Y.I.; Che, J.; Konishi, N.; Tang, Z.; Miller, A.J.; Ma, J.F.; Zhao, F.-J. Decreasing arsenic accumulation in rice by overexpressing OsNIP1;1 and OsNIP3;3 through disrupting arsenite radial transport in roots. New Phytol. 2018, 219, 641-653. [CrossRef]

46. Takemoto, Y.; Tsunemitsu, Y.; Fujii-Kashino, M.; Mitani-Ueno, N.; Yamaji, N.; Ma, J.F.; Kato, S.-I.; Iwasaki, K.; Ueno, D. The tonoplast-localized transporter MTP8.2 contributes to manganese detoxification in the shoots and roots of Oryza Sativa L. Plant Cell Physiol. 2017, 58, 1573-1582. [CrossRef]

47. Rai, H.; Yokoyama, S.; Satoh-Nagasawa, N.; Furukawa, J.; Nomi, T.; Ito, Y.; Fujimura, S.; Takahashi, H.; Suzuki, R.; Yousra, E.; et al. Cesium uptake by rice roots largely depends upon a single gene, HAK1, which encodes a potassium transporter. Plant Cell Physiol. 2017, 58, 1486-1493. [CrossRef]

48. Senoura, T.; Sakashita, E.; Kobayashi, T.; Takahashi, M.; Aung, M.S.; Masuda, H.; Nakanishi, H.; Nishizawa, N.K. The iron-chelate transporter OsYSL9 plays a role in iron distribution in developing rice grains. Plant Mol. Biol. 2017, 95, 375-387. [CrossRef]

49. Hayashi, S.; Kuramata, M.; Abe, T.; Takagi, H.; Ozawa, K.; Ishikawa, S. Phytochelatin synthase OsPCS1 plays a crucial role in reducing arsenic levels in rice grains. Plant J. 2017, 91, 840-848. [CrossRef]

50. Uraguchi, S.; Tanaka, N.; Hofmann, C.; Abiko, K.; Ohkama-Ohtsu, N.; Weber, M.; Kamiya, T.; Sone, Y.; Nakamura, R.; Takanezawa, Y.; et al. Phytochelatin synthase has contrasting effects on cadmium and arsenic accumulation in rice grains. Plant Cell Physiol. 2017, 58, 1730-1742. [CrossRef]

51. Yamaji, N.; Takemoto, Y.; Miyaji, T.; Mitani-Ueno, N.; Yoshida, K.T.; Ma, J.F. Reducing phosphorus accumulation in rice grains with an impaired transporter in the node. Nature 2017, 541, 92-95. [CrossRef]

52. Che, J.; Yokosho, K.; Yamaji, N.; Ma, J.F. A Vacuolar phytosiderophore transporter alters iron and zinc accumulation in polished rice grains. Plant Physiol. 2019, 181, 276-288. [CrossRef]

53. Aggarwal, S.; Kumar, A.; Bhati, K.K.; Kaur, G.; Shukla, V.; Tiwari, S.; Pandey, A.K. RNAi-mediated downregulation of inositol pentakisphosphate kinase (IPK1) in wheat grains decreases phytic acid levels and increases Fe and Zn Accumulation. Front. Plant Sci. 2018, 9, 259. [CrossRef]

54. Wang, J.; Sun, J.; Miao, J.; Guo, J.; Shi, Z.; He, M.; Chen, Y.; Zhao, X.; Li, B.; Han, F.; et al. A phosphate starvation response regulator Ta-PHR1 is involved in phosphate signalling and increases grain yield in wheat. Ann. Bot. 2013, 111, 1139-1153. [CrossRef]

55. Wang, L.U.; Ying, Y.; Narsai, R.; Ye, L.; Zheng, L.; Tian, J.; Whelan, J.; Shou, H. Identification of OsbHLH133 as a regulator of iron distribution between roots and shoots in Oryza Sativa. Plant Cell Environ. 2013, 36, 224-236. [CrossRef]

56. Bhati, K.K.; Alok, A.; Kumar, A.; Kaur, J.; Tiwari, S.; Pandey, A.K. Silencing of ABCC13 transporter in wheat reveals its involvement in grain development, phytic acid accumulation and lateral root formation. J. Exp. Bot. 2016, 67, 4379-4389. [CrossRef]

57. Laurie, S.; Feeney, K.A.; Maathuis, F.J.M.; Heard, P.J.; Brown, S.J.; Leigh, R.A. A role for HKT1 in sodium uptake by wheat roots. Plant J. 2002, 32, 139-149. [CrossRef]

58. Zhang, M.; Cao, Y.; Wang, Z.; Wang, Z.Q.; Shi, J.; Liang, X.; Song, W.; Chen, Q.; Lai, J.; Jiang, C. A retrotransposon in an HKT1 family sodium transporter causes variation of leaf $\mathrm{Na}^{+}$exclusion and salt tolerance in maize. New Phytol. 2018, 217, 1161-1176 [CrossRef]

59. Zhang, Y.; Chen, K.; Zhao, F.J.; Sun, C.; Jin, C.; Shi, Y.; Sun, Y.; Li, Y.; Yang, M.; Jing, X.; et al. OsATX1 interacts with heavy metal P1B-Type ATPases and affects copper transport and distribution. Plant Physiol. 2018, 178, 329-344. [CrossRef]

60. Von Wiren, N.; Mori, S.; Marschner, H.; Romheld, V. Iron inefficiency in maize mutant ys1 (Zea mays L. Cv Yellow-Stripe) is caused by a defect in uptake of iron phytosidero-phores. Plant Physiol. 1994, 106, 71-77. [CrossRef]

61. Chan-Rodriguez, D.; Walker, E.L. Analysis of yellow striped mutants of Zea mays reveals novel loci contributing to iron deficiency chlorosis. Front. Plant Sci. 2018, 9, 157. [CrossRef]

62. Qin, Y.J.; Wei-Hua, W.U.; Wang, Y.I. ZmHAK5 and ZmHAK1 function in $\mathrm{K}^{+}$uptake and distribution in maize under low $\mathrm{K}^{+}$ conditions. J. Int. Plant Biol. 2019, 61, 691-705. [CrossRef] [PubMed]

63. Durbak, A.R.; Phillips, K.A.; Pike, S.; O’Neill, M.A.; Mares, J.; Gallavotti, A.; Malcomber, S.T.; Gassmann, W.; McSteen, P. Transport of boron by the tassel-less1 aquaporin is critical for vegetative and reproductive development in maize. Plant Cell 2014, 26, 2978-2995. [CrossRef] [PubMed]

64. Gil-Díez, P.; Tejada-Jiménez, M.; León-Mediavilla, J.; Wen, J.; Mysore, K.S.; Imperial, J.; González-Guerrero, M. MtMOT1.2 is responsible for molybdate supply to Medicago truncatula nodules. Plant Cell Environ. 2018, 42, 310-320. [CrossRef]

65. Tejada-Jiménez, M.; Gil-Díez, P.; León-Mediavilla, J.; Wen, J.; Mysore, K.S.; Imperial, J.; González-Guerrero, M. Medicago truncatula Molybdate Transporter Type 1 (MtMOT1.3) is a plasma membrane molybdenum transporter required for nitrogenase activity in root nodules under molybdenum deficiency. New Phytol. 2017, 216, 1223-1235. [CrossRef] [PubMed] 
66. Tejada-Jimenez, M.; Castro-Rodriguez, R.; Igor Kryvoruchko, M.; Lucas, M.; Udvardi, M.; Imperial, J.; Gonzalez-Guerrero, M. Medicago truncatula natural resistance-associated macrophage protein1 is required for iron uptake by rhizobia-infected nodule cells. Plant Physiol. 2015, 168, 258-272. [CrossRef] [PubMed]

67. Senovilla, M.; Castro-Rodríguez, R.; Abreu, I.; Escudero, V.; Kryvoruchko, I.; Udvardi, M.K.; Imperial, J.; González-Guerrero, M. Medicago truncatula copper transporter 1 (MtCOPT1) delivers copper for symbiotic nitrogen fixation. New Phytol. 2018, 218, 696-709. [CrossRef] [PubMed]

68. León-Mediavilla, J.; Senovilla, M.; Montiel, J.; Gil-Díez, P.; Saez, A.; Kryvoruchko, I.S.; Reguera, M.; Udvardi, M.K.; Imperial, J.; González-Guerrero, M. MtMTP2-facilitated zinc transport into intracellular compartments is essential for nodule development in Medicago truncatula. Front. Plant Sci. 2018, 9, 990. [CrossRef] [PubMed]

69. Abreu, I.; Saez, A.; Castro-Rodríguez, R.; Escudero, V.; Rodríguez-Haas, B.; Senovilla, M.; Larue, C.; Grolimund, D.; TejadaJiménez, M.; Imperial, J.; et al. Medicago truncatula zinc-iron permease 6 provides zinc to rhizobia-infected nodule cells. Plant Cell Environ. 2017, 40, 2706-2719. [CrossRef]

70. White, P.J.; Brown, P.H. Plant Nutrition for Sustainable Development and Global Health. Ann. Bot. 2010, 105, 1073-1080. [CrossRef]

71. Younis, U.; Qayyum, M.F.; Shah, M.H.R.; Danish, S.; Shahzad, A.N.; Malik, S.A.; Mahmood, S. Growth, Survival, and Heavy Metal (Cd and Ni) Uptake of Spinach (Spinacia Oleracea) and Fenugreek (Trigonella Corniculata) in a Biochar-Amended Sewage-Irrigated Contaminated Soil. J. Plant Nutr. Soil Sci. 2015, 178, 209-217. [CrossRef]

72. White, P.J.; Broadley, M.R. Biofortification of Crops with Seven Mineral Elements Often Lacking in Human Diets-Iron, Zinc, Copper, Calcium, Magnesium, Selenium and Iodine. New Phytol. 2009, 182, 49-84. [CrossRef]

73. Bouis, H.E.; Saltzman, A. Improving nutrition through biofortification: A review of evidence from HarvestPlus, 2003 through 2016. Glob. Food Sec. 2017, 12, 49-58. [CrossRef]

74. Buturi, C.V.; Mauro, R.P.; Fogliano, V.; Leonardi, C.; Giuffrida, F. Mineral biofortification of vegetables as a tool to improve human diet. Foods 2021, 10, 223. [CrossRef]

75. Kanter, U.; Hauser, A.; Michalke, B.; Draxl, S.; Schäffner, A.R. Caesium and strontium accumulation in shoots of Arabidopsis thaliana: Genetic and physiological aspects. J. Exp. Bot. 2010, 61, 3995-4009. [CrossRef]

76. Pawlowski, M.L.; Helfenstein, J.; Frossard, E.; Hartman, G.L. Boron and Zinc Deficiencies and Toxicities and Their Interactions with Other Nutrients in Soybean Roots, Leaves, and Seeds. J. Plant Nutr. 2019, 42, 634-649. [CrossRef]

77. Afshan, S.; Ali, S.; Bharwana, S.A.; Rizwan, M.; Farid, M.; Abbas, F.; Ibrahim, M.; Mehmood, M.A.; Abbasi, G.H. Citric Acid Enhances the Phytoextraction of Chromium, Plant Growth, and Photosynthesis by Alleviating the Oxidative Damages in Brassica napus L. Environ. Sci. Pollut. Res. 2015, 22, 11679-11689. [CrossRef]

78. Adrees, M.; Ali, S.; Rizwan, M.; Zia-ur-Rehman, M.; Ibrahim, M.; Abbas, F.; Farid, M.; Qayyum, M.F.; Irshad, M.K. Mechanisms of Silicon-Mediated Alleviation of Heavy Metal Toxicity in Plants: A Review. Ecotoxicol. Environ. Saf. 2015, 119, 186-197. [CrossRef]

79. Liang, Y.; Sun, W.; Zhu, Y.G.; Christie, P. Mechanisms of silicon-mediated alleviation of abiotic stresses in higher plants: A review. Environ. Pollut. 2007, 147, 422-428. [CrossRef]

80. Maksimović, D.J.; Mojović, M.; Maksimović, V.; Römheld, V.; Nikolic, M. Silicon ameliorates manganese toxicity in cucumber by decreasing hydroxyl radical accumulation in the leaf apoplast. J. Exp. Bot. 2012, 63, 2411-2420. [CrossRef]

81. Punshon, T.; Jackson, B.P. Essential Micronutrient and Toxic Trace Element Concentrations in Gluten Containing and Gluten-Free Foods. Food Chem. 2018, 252, 258-264. [CrossRef]

82. Dordas, C. Role of Nutrients in Controlling Plant Diseases in Sustainable Agriculture: A Review. Agron. Sustain. Dev. 2009, 28, 33-46. [CrossRef]

83. Navarrete, F.; De La Fuente, L. Zinc Detoxification Is Required for Full Virulence and Modification of the Host Leaf Ionome by Xylella fastidiosa. Mol. Plant Microbe Interact. 2015, 28, 497-507. [CrossRef] [PubMed]

84. Walters, D.R.; Bingham, I.J. Influence of Nutrition on Disease Development Caused by Fungal Pathogens: Implications for Plant Disease Control. Ann. Appl. Biol. 2007, 151, 307-324. [CrossRef]

85. Fones, H.; Davis, C.A.R.; Rico, A.; Fang, F.; Smith, J.A.C.; Preston, G.M. Metal Hyperaccumulation Armors Plants against Disease PLoS Pathog. 2010, 6, e1001093. [CrossRef] [PubMed]

86. Hoffland, E.; Jeger, M.J.; van Beusichem, M.L. Effect of nitrogen supply rate on disease resistance in tomato depends on the pathogen. Plant Soil 2000, 218, 239-247. [CrossRef]

87. Sun, X.; Pan, B.; Wang, Y.; Xu, W.; Zhang, S. Exogenous Calcium Improved Resistance to Botryosphaeria dothidea by Increasing Autophagy Activity and Salicylic Acid Level in Pear. Mol. Plant Microbe Interact. 2020, 33, 1150-1160. [CrossRef] [PubMed]

88. Clarkson, D.T.; Marschner, H. Mineral Nutrition of Higher Plants. Second Edition. 889pp; London: Academic Press, £29.95 (Paperback). Ann. Bot. 1996, 78, 527-528. [CrossRef]

89. Cakmak, I. Tansley Review No. 111. Possible roles of zinc in protecting plant cells from damage by reactive oxygen species. New Phytol. 2000, 146, 185-205. [CrossRef] [PubMed]

90. Singh, S.; Parihar, P.; Singh, R.; Singh, V.P.; Prasad, S.M. Heavy Metal Tolerance in Plants: Role of Transcriptomics, Proteomics, Metabolomics, and Ionomics. Front. Plant Sci. 2016, 6, 1143. [CrossRef] [PubMed]

91. Kieu, N.P.; Aznar, A.; Segond, D.; Rigault, M.; Simond-Côte, E.; Kunz, C.; Soulie, M.C.; Expert, D.; Dellagi, A. Iron Deficiency Affects Plant Defence Responses and Confers Resistance to Dickeya Dadantii and Botrytis Cinerea. Mol. Plant Pathol. 2012, 13, 816-827. [CrossRef] [PubMed] 
92. Del Coco, L.; Migoni, D.; Girelli, C.R.; Angilè, F.; Scortichini, M.; Fanizzi, F.P. Soil and Leaf Ionome Heterogeneity in Xylella fastidiosa Subsp. Pauca-Infected, Non-Infected and Treated Olive Groves in Apulia, Italy. Plants 2020, 9, 760. [CrossRef]

93. Datnoff, L.E.; Rodrigues, F.A.; Seebold, K.W. Silicon and Plant Nutrition. In Mineral Nutrition and Plant Disease; Datnoff, L.E., Elmer, W.H., Huber, D.M., Eds.; American Phytopathological Society (APS Press): St. Paul, MN, USA, 2007 ; pp. $233-246$.

94. Cobine, P.A.; Cruz, L.F.; Navarrete, F.; Duncan, D.; Tygart, M.; de la Fuente, L. Xylella Fastidiosa Differentially Accumulates Mineral Elements in Biofilm and Planktonic Cells. PLoS ONE 2013, 8, e54936. [CrossRef] [PubMed]

95. De La Fuente, L.; Parker, J.K.; Oliver, J.E.; Granger, S.; Brannen, P.M.; van Santen, E.; Cobine, P.A. The Bacterial Pathogen Xylella Fastidiosa Affects the Leaf Ionome of Plant Hosts during Infection. PLoS ONE 2013, 8, e62945. [CrossRef]

96. Nicolas, O.; Charles, M.T.; Jenni, S.; Toussaint, V.; Parent, S.-É.; Beaulieu, C. The Ionomics of Lettuce Infected by Xanthomonas Campestris Pv. Vitians. Front. Plant Sci. 2019, 10, 351. [CrossRef]

97. Yuan, M.; Wang, S.; Chu, Z.; Li, X.; Xu, C. The Bacterial Pathogen Xanthomonas oryzae Overcomes Rice Defenses by Regulating Host Copper Redistribution. Plant Cell 2010, 22, 3164-3176. [CrossRef]

98. Zhao, H.; Sun, R.; Albrecht, U.; Padmanabhan, C.; Wang, A.; Coffey, M.D.; Girke, T.; Wang, Z.; Close, T.J.; Roose, M.; et al. Small RNA Profiling Reveals Phosphorus Deficiency as a Contributing Factor in Symptom Expression for Citrus Huanglongbing Disease. Mol. Plant 2013, 6, 301-310. [CrossRef]

99. Yasin, N.A.; Zaheer, M.M.; Khan, W.U.; Ahmad, S.R.; Ahmad, A.; Ali, A.; Akram, W. The beneficial role of potassium in Cd-induced stress alleviation and growth improvement in Gladiolus grandiflora L. Int. J. Phytoremediat. 2018, 20, $274-283$. [CrossRef]

100. Han, Y.; Chaouch, S.; Mhamdi, A.; Queval, G.; Zechmann, B.; Noctor, G. Functional analysis of Arabidopsis mutants points to novel roles for glutathione in coupling $\mathrm{H}_{2} \mathrm{O}_{2}$ to activation of salicylic acid accumulation and signaling. Antioxid. Redox Signal. 2013, 18, 2106-2121. [CrossRef]

101. Ghanta, S.; Bhattacharyya, D.; Sinha, R.; Banerjee, A.; Chattopadhyay, S. Nicotiana tabacum overexpressing $\gamma$-ECS exhibits biotic stress tolerance likely through NPR1-dependent salicylic acid-mediated pathway. Planta 2011, 233, 895-910. [CrossRef]

102. Yadeta, K.A.; Elmore, J.M.; Creer, A.Y.; Feng, B.; Franco, J.Y.; Rufian, J.S.; He, P.; Phinney, B.; Coaker, G. A cysteine-rich protein kinase associates with a membrane immune complex and the cysteine residues are required for cell death. Plant Physiol. 2017, 173, 771-787. [CrossRef]

103. Bollig, K.; Specht, A.; Myint, S.S.; Zahn, M.; Horst, W.J. Sulphur supply impairs spread of Verticillium dahliae in tomato. Eur. J. Plant Pathol. 2013, 135, 81-96. [CrossRef]

104. Kruse, C.; Haas, F.H.; Jost, R.; Reiser, B.; Reichelt, M.; Wirtz, M.; Gershenzon, J.; Schnug, E.; Hell, R. Improved sulfur nutrition provides the basis for enhanced production of sulfur-containing defense compounds in Arabidopsis thaliana upon inoculation with Alternaria brassicicola. J. Plant Physiol. 2012, 169, 740-743. [CrossRef] [PubMed]

105. Amtmann, A.; Troufflard, S.; Armengaud, P. The effect of potassium nutrition on pest and disease resistance in plants. Physiol. Plant. 2008, 133, 682-691. [CrossRef] [PubMed]

106. Holzmueller, E.J.; Jose, S.; Jenkins, M.A. Influence of calcium, potassium, and magnesium on Cornus florida L. density and resistance to dogwood anthracnose. Plant Soil 2007, 290, 189-199. [CrossRef]

107. Delhaize, E. A Metal-Accumulator Mutant of Arabidopsis thaliana. Plant. Physiol. 1996, 111, 849-855. [CrossRef]

108. Rogers, E.E.; Guerinot, M. Lou. FRD3, a Member of the Multidrug and Toxin Efflux Family, Controls Iron Deficiency Responses in Arabidopsis. Plant Cell 2002, 14, 1787-1799. [CrossRef]

109. Durrett, T.P.; Gassmann, W.; Rogers, E.E. The FRD3-Mediated Efflux of Citrate into the Root Vasculature Is Necessary for Efficient Iron Translocation. Plant Physiol. 2007, 144, 197-205. [CrossRef]

110. Rus, A.; Baxter, I.; Muthukumar, B.; Gustin, J.; Lahner, B.; Yakubova, E.; Salt, D.E. Natural Variants of AtHKT1 Enhance Na Accumulation in Two Wild Populations of Arabidopsis. PLoS Genet. 2006, 2, e210. [CrossRef]

111. Baxter, I.; Brazelton, J.N.; Yu, D.; Huang, Y.S.; Lahner, B.; Yakubova, E.; Li, Y.; Bergelson, J.; Borevitz, J.O.; Nordborg, M.; et al. A Coastal Cline in Sodium Accumulation in Arabidopsis thaliana is Driven by Natural Variation of the Sodium Transporter AtHKT1;1. PLoS Genet. 2010, 6, e1001193. [CrossRef]

112. Loudet, O.; Saliba-Colombani, V.; Camilleri, C.; Calenge, F.; Gaudon, V.; Koprivova, A.; North, K.A.; Kopriva, S.; Daniel-Vedele, F. Natural Variation for Sulfate Content in Arabidopsis thaliana is Highly Controlled by APR2. Nat. Genet. 2007, 39, 896-900. [CrossRef]

113. Baxter, I.; Muthukumar, B.; Park, H.C.; Buchner, P.; Lahner, B.; Danku, J.; Zhao, K.; Lee, J.; Hawkesford, M.J.; Guerinot, M.; et al. Variation in Molybdenum Content Across Broadly Distributed Populations of Arabidopsis thaliana Is Controlled by a Mitochondrial Molybdenum Transporter (MOT1). PLoS Genet. 2008, 4, e1000004. [CrossRef]

114. Poormohammad Kiani, S.; Trontin, C.; Andreatta, M.; Simon, M.; Robert, T.; Salt, D.E.; Loudet, O. Allelic Heterogeneity and Trade-Off Shape Natural Variation for Response to Soil Micronutrient. PLoS Genet. 2012, 8, e1002814. [CrossRef]

115. Baxter, I.; Hosmani, P.S.; Rus, A.; Lahner, B.; Borevitz, J.O.; Muthukumar, B.; Mickelbart, M.V.; Schreiber, L.; Franke, R.B.; Salt, D.E. Root Suberin Forms an Extracellular Barrier That Affects Water Relations and Mineral Nutrition in Arabidopsis. PLoS Genet. 2009, 5, e1000492. [CrossRef]

116. Hosmani, P.S.; Kamiya, T.; Danku, J.; Naseer, S.; Geldner, N.; Guerinot, M.L.; Salt, D.E. Dirigent Domain-Containing Protein Is Part of the Machinery Required for Formation of the Lignin-Based Casparian Strip in the Root. Proc. Natl. Acad. Sci. USA 2013, 110, 14498-14503. [CrossRef] 
117. Tian, H.; Baxter, I.R.; Lahner, B.; Reinders, A.; Salt, D.E.; Ward, J.M. Arabidopsis NPCC6/NaKR1 Is a Phloem Mobile Metal Binding Protein Necessary for Phloem Function and Root Meristem Maintenance. Plant Cell 2010, 22, 3963-3979. [CrossRef]

118. Alassimone, J.; Fujita, S.; Doblas, V.G.; van Dop, M.; Barberon, M.; Kalmbach, L.; Vermeer, J.E.M.; Rojas-Murcia, N.; Santuari, L.; Hardtke, C.S.; et al. Polarly Localized Kinase SGN1 Is Required for Casparian Strip Integrity and Positioning. Nat. Plants 2016, 2, 16113. [CrossRef]

119. Borghi, M.; Rus, A.; Salt, D.E. Loss-of-Function of Constitutive Expresser of Pathogenesis Related Genes5 Affects Potassium Homeostasis in Arabidopsis thaliana. PLoS ONE 2011, 6, e26360. [CrossRef]

120. Chao, D.Y.; Gable, K.; Chen, M.; Baxter, I.; Dietrich, C.R.; Cahoon, E.B.; Guerinot, M.L.; Lahner, B.; Lü, S.; Markham, J.E.; et al. Sphingolipids in the Root Play an Important Role in Regulating the Leaf Ionome in Arab. Thaliana. Plant Cell 2011, 23, $1061-1081$. [CrossRef]

121. Chao, D.-Y.; Silva, A.; Baxter, I.; Huang, Y.S.; Nordborg, M.; Danku, J.; Lahner, B.; Yakubova, E.; Salt, D.E. Genome-Wide Association Studies Identify Heavy Metal ATPase3 as the Primary Determinant of Natural Variation in Leaf Cadmium in Arabidopsis thaliana. PLoS Genet. 2012, 8, e1002923. [CrossRef]

122. Koprivova, A.; Giovannetti, M.; Baraniecka, P.; Lee, B.R.; Grondin, C.; Loudet, O.; Kopriva, S. Natural Variation in the ATPS1 Isoform of ATP Sulfurylase Contributes to the Control of Sulfate Levels in Arabidopsis. Plant Physiol. 2013, 163, 1133-1141. [CrossRef]

123. Pfister, A.; Barberon, M.; Alassimone, J.; Kalmbach, L.; Lee, Y.; Vermeer, J.E.M.; Yamazaki, M.; Li, G.; Maurel, C.; Takano, J.; et al. A Receptor-like Kinase Mutant with Absent Endodermal Diffusion Barrier Displays Selective Nutrient Homeostasis Defects. eLife 2014, 3, e03115. [CrossRef]

124. Chao, D.Y.; Chen, Y.; Chen, J.; Shi, S.; Chen, Z.; Wang, C.; Danku, J.M.; Zhao, F.J.; Salt, D.E. Genome-wide Association Mapping identifies a New Arsenate Reductase Enzyme Critical for Limiting Arsenic Accumulation in Plants. PLoS Biol. 2014, 12, e1002009. [CrossRef]

125. Stolpe, C.; Giehren, F.; Krämer, U.; Müller, C. Both Heavy Metal-Amendment of Soil and Aphid-Infestation Increase Cd and Zn Concentrations in Phloem Exudates of a Metal-Hyperaccumulating Plant. Phytochemistry 2017, 139, 109-117. [CrossRef]

126. Kumar, S.; Parekh, M.J.; Patel, C.B.; Zala, H.N.; Sharma, R.; Kulkarni, K.S.; Fougat, R.S.; Bhatt, R.K.; Sakure, A.A. Development and Validation of EST-Derived SSR Markers and Diversity Analysis in Cluster Bean (Cyamopsis tetragonoloba). J. Plant Biochem. Biotechnol. 2016, 25, 263-269. [CrossRef]

127. Wang, Y.Q.; Feechan, A.; Yun, B.W.; Shafiei, R.; Hofmann, A.; Taylor, P.; Xue, P.; Yang, F.Q.; Xie, Z.S.; Pallas, J.A.; et al. SNitrosylation of AtSABP3 Antagonizes the Expression of Plant Immunity. J. Biol. Chem. 2009, 284, 2131-2137. [CrossRef] [PubMed]

128. Calic, I.; Koch, J.; Carey, D.; Addo-Quaye, C.; Carlson, J.E.; Neale, D.B. Genome-Wide Association Study Identifies a Major Gene for Beech Bark Disease Resistance in American Beech (Fagus grandifolia Ehrh.). BMC Genom. 2017, 18, 547. [CrossRef] [PubMed]

129. Wang, X.; Wang, Y.; Liu, P.; Ding, Y.; Mu, X.; Liu, X.; Wang, X.; Zhao, M.; Huai, B.; Huang, L.; et al. TaRar1 Is Involved in Wheat Defense against Stripe Rust Pathogen Mediated by YrSu. Front. Plant Sci. 2017, 8, 156. [CrossRef] [PubMed]

130. Jia, X.; Zhu, Y.; Zhang, R.; Zhu, Z.; Zhao, T.; Cheng, L.; Gao, L.; Liu, B.; Zhang, X.; Wang, Y. Ionomic and Metabolomic Analyses Reveal the Resistance Response Mechanism to Saline-Alkali Stress in Malus halliana Seedlings. Plant Physiol. Biochem. 2020, 147, 77-90. [CrossRef] [PubMed]

131. Pilon-Smits, E.A.; Quinn, C.F.; Tapken, W.; Malagoli, M.; Schiavon, M. Physiological Functions of Beneficial Elements. Curr. Opin Plant Biol. 2009, 12, 267-274. [CrossRef] [PubMed]

132. Deshmukh, R.; Sonah, H.; Patil, G.; Chen, W.; Prince, S.; Mutava, R.; Vuong, T.; Valliyodan, B.; Nguyen, H.T. Integrating Omic Approaches for Abiotic Stress Tolerance in Soybean. Front. Plant Sci. 2014, 244. [CrossRef]

133. Ahmad, P.; Abd Allah, E.F.; Alyemeni, M.N.; Wijaya, L.; Alam, P.; Bhardwaj, R.; Siddique, K.H.M. Exogenous Application of Calcium to 24-Epibrassinosteroid Pre-Treated Tomato Seedlings Mitigates NaCl Toxicity by Modifying Ascorbate-Glutathione Cycle and Secondary Metabolites. Sci. Rep. 2018, 8, 13515. [CrossRef]

134. Pankovic, D. Effects of Nitrogen Nutrition on Photosynthesis in Cd-Treated Sunflower Plants. Ann. Bot. 2000, 86, 841-847. [CrossRef]

135. Sarwar, N.; Malhi, S.S.; Zia, M.H.; Naeem, A.; Bibi, S.; Farid, G. Role of mineral nutrition in minimizing cadmium accumulation by plants. J. Sci. Food Agric. 2010, 90, 925-937. [CrossRef]

136. Riyazuddin, R.; Verma, R.; Singh, K.; Nisha, N.; Keisham, M.; Bhati, K.K.; Kim, S.T.; Gupta, R. Ethylene: A master regulator of salinity stress tolerance in plants. Biomolecules 2020, 10, 959. [CrossRef]

137. Astolfi, S.; Zuchi, S. Adequate $S$ supply protects barley plants from adverse effects of salinity stress by increasing thiol contents. Acta Physiol. Plant. 2013, 35, 175-181. [CrossRef]

138. Usmani, M.M.; Nawaz, F.; Majeed, S. Sulfate-mediated Drought Tolerance in Maize Involves Regulation at Physiological and Biochemical Levels. Sci Rep. 2020, 10, 1147. [CrossRef]

139. Misra, B.B.; Reichman, S.M.; Chen, S. The guard cell ionome: Understanding the role of ions in guard cell functions. Prog. Biophys. Mol. Biol. 2019, 146, 50-62. [CrossRef]

140. Abid, M.; Schneider, U.A.; Scheffran, J. Adaptation to Climate Change and Its Impacts on Food Productivity and Crop Income: Perspectives of Farmers in Rural Pakistan. J. Rural Stud. 2016, 47, 254-266. [CrossRef] 
141. Luo, Z.; Kong, X.; Dai, J.; Dong, H. Soil plus foliar nitrogen application increases cotton growth and salinity tolerance. J. Plant Nutr. 2015, 38, 443-455. [CrossRef]

142. Khan, A.; Ahmad, I.; Shah, A.; Ahmad, F.; Ghani, A.; Nawaz, M.; Shaheen, F.; Fatima, H.U.; Pervaiz, F.; Javed, S.; et al. Amelioration of Salinity Stress in Wheat (Triticum Aestivum) by Foliar Application of Phosphorus. Phyton 2013, 82, $281-287$.

143. Lopez-Delacalle, M.; Camejo, D.M.; García-Martí, M.; Nortes, P.A.; Nieves-Cordones, M.; Martínez, V.; Rubio, F.; Mittler, R.; Rivero, R.M. Using Tomato Recombinant Lines to Improve Plant Tolerance to Stress Combination Through a More Efficient Nitrogen Metabolism. Front. Plant Sci. 2020, 10, 1702. [CrossRef] [PubMed]

144. Brito, C.; Dinis, L.T.; Ferreira, H.; Coutinho, J.; Moutinho-Pereira, J.; Correia, C.M. Salicylic acid increases drought adaptability of young olive trees by changes on redox status and ionome. Plant Physiol. Biochem. 2019, 141, 315-324. [CrossRef] [PubMed]

145. Abbas, S.; Javed, M.T.; Ali, Q.; Akram, M.S.; Tanwir, K.; Ali, S.; Chaudhary, H.J.; Iqbal, N. Elucidating Cd-mediated distinct rhizospheric and in planta ionomic and physio-biochemical responses of two contrasting Zea mays L. cultivars. Physiol. Mol. Biol. Plants 2021, 27, 297-312. [CrossRef]

146. Lee, B.-R.; Zaman, R.; Avice, J.-C.; Ourry, A.; Kim, T.H. Sulfur Use Efficiency is a Significant Determinant of Drought Stress Tolerance in Relation to Photosynthetic Activity in Brassica napus Cultivars. Front. Plant Sci. 2016, 7, 459. [CrossRef] [PubMed]

147. Hossain, A.; Skalicky, M.; Brestic, M.; Maitra, S.; Ashraful Alam, M.; Syed, M.A.; Hossain, J.; Sarkar, S.; Saha, S.; Bhadra, P.; et al. Consequences and Mitigation Strategies of Abiotic Stresses in Wheat (Triticum aestivum L.) under the Changing Climate. Agronomy 2021, 11, 241. [CrossRef]

148. Peng, C.Y.; Xu, X.F.; Zhu, H.Y.; Ren, Y.F.; Niu, H.L.; Hou, R.Y.; Wan, X.C.; Cai, H.M. Metabolics and ionomics responses of tea leaves (Camellia sinensis (L.) O. Kuntze) to fluoride stress. Plant Physiol. Biochem. 2021, 158, 65-75. [CrossRef]

149. Banerjee, A.; Singh, A.; Sudarshan, M.; Roychoudhury, A. Silicon Nanoparticle-Pulsing Mitigates Fluoride Stress in Rice by Fine-Tuning the Ionomic and Metabolomic Balance and Refining Agronomic Traits. Chemosphere 2021, 262, 127826. [CrossRef]

150. Ahmad, P.; Ahanger, M.A.; Alam, P. Silicon (Si) Supplementation Alleviates NaCl Toxicity in Mung Bean [Vigna radiata (L. ) Wilczek] Through the Modifications of Physio-biochemical Attributes and Key Antioxidant Enzymes. J. Plant Growth Regul. 2019, 38, 70-82. [CrossRef]

151. Pandit, A.; Rai, V.; Bal, S.; Sinha, S.; Kumar, V.; Chauhan, M.; Gautam, R.K.; Singh, R.; Sharma, P.C.; Singh, A.K.; et al. Combining QTL Mapping and Transcriptome Profiling of Bulked RILs for Identification of Functional Polymorphism for Salt Tolerance Genes in Rice (Oryza sativa L.). Mol. Genet. Genom. 2010, 284, 121-136. [CrossRef]

152. Sonah, H.; O’Donoughue, L.; Cober, E.; Rajcan, I.; Belzile, F. Identification of Loci Governing Eight Agronomic Traits Using a GBS-GWAS Approach and Validation by QTL Mapping in Soya Bean. Plant Biotechnol. J. 2015, 13, 211-221. [CrossRef]

153. Deshmukh, R.; Singh, A.; Jain, N.; Anand, S.; Gacche, R.; Singh, A.; Gaikwad, K.; Sharma, T.; Mohapatra, T.; Singh, N. Identification of Candidate Genes for Grain Number in Rice (Oryza sativa L.). Funct. Integr. Genom. 2010, 10, 339-347. [CrossRef]

154. Sonah, H.; Deshmukh, R.; Chand, S.; Srinivasprasad, M.; Rao, G.; Upreti, H.; Singh, A.; Singh, N.; Sharma, T. Molecular Mapping of Quantitative Trait Loci for Flag Leaf Length and Other Agronomic Traits in Rice (Oryza sativa). Cereal Res. Commun. 2012, 40, 362-372. [CrossRef]

155. Bentsink, L.; Yuan, K.; Koornneef, M.; Vreugdenhil, D. The Genetics of Phytate and Phosphate Accumulation in Seeds and Leaves of Arabidopsis thaliana, Using Natural Variation. Theor. Appl. Genet. 2003, 106, 1234-1243. [CrossRef]

156. Payne, K.A.; Bowen, H.C.; Hammond, J.P.; Hampton, C.R.; Lynn, J.R.; Mead, A.; Swarup, K.; Bennett, M.J.; White, P.J.; Broadley, M.R. Natural Genetic Variation in Caesium (Cs) Accumulation by Arabidopsis thaliana. New Phytol. 2004, 162, 535-548. [CrossRef]

157. Rauh, B.L.; Basten, C.; Buckler IV, E.S. Quantitative Trait Loci Analysis of Growth Response to Varying Nitrogen Sources in Arab. Thaliana. Theor. Appl. Genet. 2002, 104, 743-750. [CrossRef]

158. Hoekenga, O.A.; Maron, L.G.; Piñeros, M.A.; Cançado, G.M.A.; Shaff, J.; Kobayashi, Y.; Ryan, P.R.; Dong, B.; Delhaize, E.; Sasaki, T.; et al. AtALMT1, Which Encodes a Malate Transporter, Is Identified as One of Several Genes Critical for Aluminum Tolerance in Arabidopsis. Proc. Natl. Acad. Sci. USA 2006, 103, 9738-9743. [CrossRef]

159. Buescher, E.; Achberger, T.; Amusan, I.; Giannini, A.; Ochsenfeld, C.; Rus, A.; Lahner, B.; Hoekenga, O.; Yakubova, E.; Harper, J.F.; et al. Natural Genetic Variation in Selected Populations of Arabidopsis thaliana Is Associated with Ionomic Differences. PLoS ONE 2010, 5, e11081. [CrossRef]

160. Tiwari, V.K.; Rawat, N.; Chhuneja, P.; Neelam, K.; Aggarwal, R.; Randhawa, G.S.; Dhaliwal, H.S.; Keller, B.; Singh, K. Mapping of Quantitative Trait Loci for Grain Iron and Zinc Concentration in Diploid a Genome Wheat. J. Hered. 2009, 100, 771-776. [CrossRef]

161. Liu, J.; Yang, J.; Li, R.; Shi, L.; Zhang, C.; Long, Y.; Xu, F.; Meng, J. Analysis of Genetic Factors That Control Shoot Mineral Concentrations in Rapeseed (Brassica napus) in Different Boron Environments. Plant. Soil 2009, 320, 255-266. [CrossRef]

162. Satismruti, K.; Senthil, N.; Vellaikumar, S.; Ranjani, R.V.; Raveendran, M. Plant Ionomics: A Platform for Identifying Novel Gene Regulating Plant Mineral Nutrition. Am. J. Plant Sci. 2013, 4, 1309-1315. [CrossRef]

163. Chaudhary, J.; Patil, G.B.; Sonah, H.; Deshmukh, R.K.; Vuong, T.D.; Valliyodan, B.; Nguyen, H.T. Expanding Omics Resources for Improvement of Soybean Seed Composition Traits. Front. Plant Sci. 2015, 6, 1021. [CrossRef]

164. Xu, X.; Zeng, L.; Tao, Y.; Vuong, T.; Wan, J.; Boerma, R.; Noe, J.; Li, Z.; Finnerty, S.; Pathan, S.M.; et al. Pinpointing Genes Underlying the Quantitative Trait Loci for Root-Knot Nematode Resistance in Palaeopolyploid Soybean by Whole Genome Resequencing. Proc. Natl. Acad. Sci. USA 2013, 110, 13469-13474. [CrossRef] 
165. Deshmukh, R.; Bélanger, R.R. Molecular Evolution of Aquaporins and Silicon Influx in Plants. Funct. Ecol. 2016, 30 , 1277-1285. [CrossRef]

166. Deshmukh, R.K.; Ma, J.F.; Bélanger, R.R. Editorial: Role of Silicon in Plants. Front. Plant Sci. 2017, 8, 1858. [CrossRef]

167. Kadam, S.; Vuong, T.D.; Qiu, D.; Meinhardt, C.G.; Song, L.; Deshmukh, R.; Patil, G.; Wan, J.; Valliyodan, B.; Scaboo, A.M.; et al. Genomic-Assisted Phylogenetic Analysis and Marker Development for next Generation Soybean Cyst Nematode Resistance Breeding. Plant Sci. 2016, 242, 342-350. [CrossRef]

168. Induri, B.R.; Ellis, D.R.; Slavov, G.T.; Yin, T.; Zhang, X.; Muchero, W.; Tuskan, G.A.; DiFazio, S.P. Identification of Quantitative Trait Loci and Candidate Genes for Cadmium Tolerance in Populus. Tree Physiol. 2012, 32, 626-638. [CrossRef]

169. Ziegler, G.; Nelson, R.; Granada, S.; Krishnan, H.B.; Gillman, J.D.; Baxter, I. Genomewide Association Study of Ionomic Traits on Diverse Soybean Populations from Germplasm Collections. Plant Direct 2017, 2, e00033. [CrossRef]

170. Yang, M.; Lu, K.; Zhao, F.J.; Xie, W.; Ramakrishna, P.; Wang, G.; Du, Q.; Liang, L.; Sun, C.; Zhao, H.; et al. Genome-Wide Association Studies Reveal the Genetic Basis of Ionomic Variation in Rice. Plant Cell 2018, 30, 2720-2740. [CrossRef] [PubMed]

171. Norton, G.J.; Deacon, C.M.; Xiong, L.; Huang, S.; Meharg, A.A.; Price, A.H. Genetic mapping of the rice ionome in leaves and grain: Identification of QTLs for 17 elements including arsenic, cadmium, iron and selenium. Plant Soil 2010, 329, 139-153. [CrossRef]

172. Blair, M.W.; Wu, X.; Bhandari, D.; Astudillo, C. Genetic Dissection of ICP-Detected Nutrient Accumulation in the Whole Seed of Common Bean (Phaseolus vulgaris L.). Front. Plant Sci. 2016, 7, 219. [CrossRef] [PubMed]

173. Lowry, D.B.; Sheng, C.C.; Zhu, Z.; Juenger, T.E.; Lahner, B.; Salt, D.E.; Willis, J.H. Mapping of ionomic traits in Mimulus guttatus reveals Mo and Cd QTLs that colocalize with MOT1 homologues. PLoS ONE 2012, 7, e30730. [CrossRef]

174. Gyawali, S.; Otte, M.L.; Chao, S.; Jilal, A.; Jacob, D.L.; Amezrou, R.; Verma, R.P.S. Genome wide association studies (GWAS) of element contents in grain with a special focus on zinc and iron in a world collection of barley (Hordeum vulgare L.). J. Cereal Sci. 2017, 77, 266-274. [CrossRef]

175. Bastien, M.; Sonah, H.; Belzile, F. Genome Wide Association Mapping of Sclerotinia Sclerotiorum Resistance in Soybean with a Genotyping-by-Sequencing Approach. Plant Genome 2014, 7. [CrossRef]

176. Tardivel, A.; Sonah, H.; Belzile, F.; O’Donoughue, L.S. Rapid Identification of Alleles at the Soybean Maturity Gene E3 Using Genotyping by Sequencing and a Haplotype-Based Approach. Plant Genome 2014, 7. [CrossRef]

177. Iquira, E.; Humira, S.; François, B. Association Mapping of QTLs for Sclerotinia Stem Rot Resistance in a Collection of Soybean Plant Introductions Using a Genotyping by Sequencing (GBS) Approach. BMC Plant Biol. 2015, 15, 5. [CrossRef]

178. Weigel, D.; Nordborg, M. Population Genomics for Understanding Adaptation in Wild Plant Species. Annu. Rev. Genet. 2015, 49, 315-338. [CrossRef]

179. Atwell, S.; Huang, Y.; Vilhjálmsson, B.; Willmems, G.; Horton, M.; Li, Y.; Meng, D.; Platt, A.; Tarone, A.M.; Hu, T.T.; et al. Genome-wide association study of 107 phenotypes in Arabidopsis thaliana inbred lines. Nature 2010, 465, 627-631. [CrossRef]

180. Mills, R.F.; Valdes, B.; Duke, M.; Peaston, K.A.; Lahner, B.; Salt, D.E.; Williams, L.E. Functional significance of AtHMA4 C-Terminal Domain in Planta. PLoS ONE 2010, 5, e13388. [CrossRef]

181. Hanikenne, M.; Talke, I.N.; Haydon, M.J.; Lanz, C.; Nolte, A.; Motte, P.; Kroymann, J.; Weigel, D.; Krämer, U. Evolution of metal hyperaccumulation required cis-regulatory changes and triplication of HMA4. Nature 2008, 453, 391-395. [CrossRef]

182. Zhang, H.; Wang, M.L.; Schaefer, R.; Dang, P.; Jiang, T.; Chen, C. GWAS and Coexpression Network Reveal Ionomic Variation in Cultivated Peanut. J. Agric. Food Chem. 2019, 67, 12026-12036. [CrossRef]

183. Descalsota-Empleo, G.I.; Amparado, A.; Inabangan-Asilo, M.A.; Tesoro, F.; Stangoulis, J.; Reinke, R.; Swamy, B.P.M. Genetic Mapping of QTL for Agronomic Traits and Grain Mineral Elements in Rice. Crop J. 2019, 7, 560-572. [CrossRef]

184. Fikas, A.A.; Dilkes, B.P.; Baxter, I. Multivariate Analysis Reveals Environmental and Genetic Determinants of Element Covariation in the Maize Grain Ionome. Plant Direct 2019, 3, e00139. [CrossRef]

185. Liu, S.; Zhong, H.; Meng, X.; Sun, T.; Li, Y.; Pinson, S.R.; Chang, S.K.; Peng, Z. Genome-wide association studies of ionomic and agronomic traits in USDA mini core collection of rice and comparative analyses of different mapping methods. BMC Plant Biol. 2020, 20, 441. [CrossRef]

186. Li, G.; Nunes, L.; Wang, Y.; Williams, P.N.; Zheng, M.; Zhang, Q.; Zhu, Y. Profiling the ionome of rice and its use in discriminating geographical origins at the regional scale. China J. Environ. Sci. 2013, 25, 144-154. [CrossRef]

187. Wickramasinghe, W.A.; Anusha, D.L.; Mubiana, V.K.; Blust, R. The Effects of Heavy Metal Concentration on Bio-Accumulation, Productivity and Pigment Content of Two Species of Marine Macro Algae. Sri Lanka J. Aquat. Sci. 2017, 22. [CrossRef]

188. Ardini, F.; Soggia, F.; Abelmoschi, M.L.; Magi, E.; Grotti, M. Ionomic profiling of Nicotiana langsdorffii wild-type and mutant genotypes exposed to abiotic stresses. Anal. Bioanal. Chem. 2013, 405, 665-677. [CrossRef]

189. Chen, A.; Hansen, T.H.; Olsen, L.I.; Palmgren, M.; Husted, S.; Schjoerring, J.K.; Persson, D.P. Towards single-cell ionomics: A novel micro-scaled method for multi-element analysis of nanogram-sized biological samples. Plant Methods 2020, 16, 31. [CrossRef]

190. Ko, J.A.; Furuta, N.; Lim, H. Bin. Quantitative Mapping of Elements in Basil Leaves (Ocimum basilicum) Based on Cesium Concentration and Growth Period Using Laser Ablation ICP-MS. Chemosphere 2018, 190, 368-374. [CrossRef]

191. Leśniewicz, A.; Zyrnicki, W. Extraction of Trace Elements from Spruce Needles. Commun. Soil Sci. Plant. Anal. 2003, 34, 629-643. [CrossRef] 
192. Galinha, C.; Freitas, M.C.; Pacheco, A.M.G. Enrichment factors and transfer coefficients from soil to rye plants by INAA. J. Radioanal. Nucl. Chem. 2010, 286, 583-589. [CrossRef]

193. Hamidatou, L.; Slamene, H.; Akhal, T.; Zouranen, B. Concepts, Instrumentation and Techniques of Neutron Activation Analysis. In Imaging and Radioanalytical Techniques in Interdisciplinary Research-Fundamentals and Cutting Edge Applications; InTechOpen: Rijeka, Croatia: London, UK, 2013; pp. 141-178. [CrossRef]

194. Adomako, D.; Nyarko, B.J.B.; Dampare, S.B.; Serfor-Armah, Y.; Osae, S.; Fianko, J.R.; Akaho, E.H.K. Determination of toxic elements in waters and sediments from River Subin in the Ashanti Region of Ghana. Environ. Monit. Assess. 2008, 141, 165-175. [CrossRef] [PubMed]

195. Messaoudi, M.; Begaa, S.; Hamidatou, L.; Salhi, M. Determination of selenium in roasted beans coffee samples consumed in Algeria by radiochemical neutron activation analysis method. Radiochim. Acta 2018, 106, 141-146. [CrossRef]

196. Djingova, R.; Mihaylova, V.; Lyubomirova, V.; Tsalev, D.L. Multielement Analytical Spectroscopy in Plant Ionomics Research. Appl. Spectrosc. Rev. 2013, 48, 384-424. [CrossRef]

197. Bamford, S.; Wegrzynek, D.; Chinea-Cano, E.; Markowicz, A. Application of X-ray fluorescence techniques for the determination of hazardous and essential trace elements in environmental and biological materials. Nukleonika 2004, 49, 87-95.

198. Young, L.W.; Westcott, N.D.; Attenkofer, K.; Reaney, M.J.T. A High-Throughput Determination of Metal Concentrations in Whole Intact Arabidopsis thaliana Seeds Using Synchrotron-Based X-Ray Fluorescence Spectroscopy. J. Synchrotron. Radiat. 2006, 13, 304-313. [CrossRef]

199. Ratcliffe, S.; Jugdaohsingh, R.; Vivancos, J.; Marron, A.; Deshmukh, E.R.; Ma, J.F.; Mitani-Ueno, N.; Robertson, J.; Wills, J.; Boekschoten, M.V.; et al. Identification of a mammalian silicon transporter. Am. J. Physiol. Cell Physiol. 2017, 312, C550-C561. [CrossRef]

200. Ouellette, S.; Marie-Hélène, G.; Labbé, C.; Laur, J.; Gaudreau, L.; Gosselin, A.; Dorais, M.; Deshmukh, R.K.; Bélanger, R.R. Silicon transporters and effects of silicon amendments in strawberry under high tunnel and field conditions. Front. Plant Sci. 2017, 8, 949. [CrossRef]

201. Shivaraj, S.M.; Deshmukh, R.; Bhat, J.A.; Sonah, H.; Bélanger, R.R. Understanding aquaporin transport system in eelgrass (Zostera marina L.), an aquatic plant species. Front. Plant Sci. 2017, 8, 1334. [CrossRef]

202. Fahrni, C.J. Biological applications of X-ray fluorescence microscopy: Exploring the subcellular topography and speciation of transition metals. Curr. Opin. Chem. Biol. 2007, 11, 121-127. [CrossRef]

203. Qin, Z.; Caruso, J.A.; Lai, B.; Matusch, A.; Becker, J.S. Trace metal imaging with high spatial resolution: Applications in biomedicine. Metallomics 2011, 3, 28-37. [CrossRef]

204. Sarret, G.; Schroeder, W.H.; Marcus, M.A.; Geoffroy, N.; Manceau, A. Localization and speciation of Zn in mycorrhized roots by $\mu$ SXRF and $\mu$ EXAFS. J. Phys. 2003, 107, 1193-1196.

205. Bulska, E.; Wysocka, I.A.; Wierzbicka, M.L.; Proost, K.; Janssens, K.; Falkenberg, G. In vivo investigation of the distribution and the local speciation of selenium in Allium cepa L. by means of microscopic X-ray absorption near-edge structure spectroscopy and confocal microscopic X-ray fluorescence analysis. Anal Chem. 2006, 78, 7616-7624. [CrossRef]

206. Meharg, A.A.; Williams, P.N.; Adomako, E.; Lawgali, Y.Y.; Deacon, C.; Villada, A.; Cambell, R.C.; Sun, G.; Zhu, Y.G.; Feldmann, J.; et al. Geographical variation in total and inorganic arsenic content of polished (white) rice. Environ. Sci. Technol. 2009, 43, 1612-1617. [CrossRef]

207. Takahashi, M.; Nozoye, T.; Kitajima, N.; Fukuda, N.; Hokura, A.; Terada, Y.; Nakai, I.; Ishimaru, Y.; Kobayashi, T.; Nakanishi, H.; et al. In vivo analysis of metal distribution and expression of metal transporters in rice seed during germination process by microarray and X-ray fluorescence imaging of Fe, Zn, Mn, and Cu. Plant Soil 2009, 325, 39-51. [CrossRef]

208. Ricachenevsky, F.K.; Punshon, T.; Lee, S.; Oliveira, B.H.N.; Trenz, T.S.; Maraschin, F.S.; Hindt, M.N.; Danku, J.; Salt, D.E.; Fett, J.P.; et al. Elemental Profiling of Rice FOX Lines Leads to Characterization of a New Zn Plasma Membrane Transporter, OsZIP7. Front. Plant Sci. 2018, 9, 865. [CrossRef]

209. Hacisalihoglu, G.; Settles, A.M. Quantification of seed ionome variation in 90 diverse soybean (Glycine max) lines. J. Plant Nutr. 2017, 40, 2808-2817. [CrossRef]

210. Li, H.; Zhu, Y.; Hu, Y.; Han, W.; Gong, H. Beneficial effects of silicon in alleviating salinity stress of tomato seedlings grown under sand culture. Acta Physiol. Plant. 2015, 37, 71. [CrossRef]

211. Chen, Z.; Watanabe, T.; Shinano, T.; Ezawa, T.; Wasaki, J.; Kimura, K.; Osaki, M.; Zhu, Y.G. Element interconnections in Lotus japonicus: A systematic study of the effects of element additions on different natural variants. Soil Sci. Plant Nutr. 2008, 55, 91-101. [CrossRef]

212. Wu, D.; Shen, Q.; Cai, S.; Chen, Z.H.; Dai, F.; Zhang, G. Ionomic Responses and Correlations Between Elements and Metabolites Under Salt Stress in Wild and Cultivated Barley. Plant Cell Physiol. 2013, 54, 1976-1988. [CrossRef]

213. Begaa, S.; Messaoudi, M.; Benarfa, A. Statistical Approach and Neutron Activation Analysis for Determining Essential and Toxic Elements in Two Kinds of Algerian Artemisia Plant. Biol. Trace Elem. Res. 2021, 199, 2399-2405. [CrossRef]

214. Barbosa, J.T.P.; Santos, C.M.M.; Dos Santos Bispo, L.; Lyra, F.H.; David, J.M.; Korn, M.D.G.A.; Flores, E.M.M. Bromine, Chlorine, and Iodine Determination in Soybean and its Products by ICP-MS After Digestion Using Microwave-Induced Combustion. Food Anal. Methods 2013, 6, 1065-1070. [CrossRef]

215. Xu, Z.; Ren, T.; Marowa, P.; You, X.; Lu, X.; Li, Y.; Zhang, C. Establishment of a Cultivation Mode of Glycine soja, the Bridge of Phytoremediation and Industrial Utilization. Agronomy 2020, 10, 595. [CrossRef] 
216. Sanchez, D.H.; Pieckenstain, F.L.; Escaray, F.; Erban, A.; Kraemer, U.; Udvardi, M.K.; Kopka, J. Comparative ionomics and metabolomics in extremophile and glycophytic Lotus species under salt stress challenge the metabolic pre-adaptation hypothesis. Plant Cell Environ. 2011, 34, 605-617. [CrossRef]

217. Da Costa, L.F.; Tormena, C.F.; Arruda, M.A.Z. Ionomics and lipidomics for evaluating the transgenic (cp4-EPSPS gene) and non-transgenic soybean seed generations. Microchem. J. 2021, 165, 106130. [CrossRef]

218. Jyothsna, S.; Manjula, G.; Suthari, S.; Rao, A.S.N. Qualitative elemental analysis of selected potential anti-asthmatic medicinal plant taxa using EDXRF technique. Heliyon 2020, 6, e03260. [CrossRef]

219. Dragut, E.C.; Ouzzani, M.; Madkour, A.; Mohamed, N.; Baker, P.; Salt, D.E. Lonomics Atlas: A tool to explore interconnected ionomic, genomic and environmental data. In Proceedings of the 21st ACM International Conference on Information and Knowledge Management, Maui, HI, USA, 29 October-2 November 2012; pp. 2680-2682.

220. Zhang, M.; Pinson, S.R.; Tarpley, L.; Huang, X.Y.; Lahner, B.; Yakubova, E.; Baxter, I.; Guerinot, M.L.; Salt, D.E. Mapping and validation of quantitative trait loci associated with concentrations of 16 elements in unmilled rice grain. Theor. Appl. Genet. 2014, 127, 37-165. [CrossRef]

221. Yu, D.; Danku, J.M.; Baxter, I.; Kim, S.; Vatamaniuk, O.K.; Vitek, O.; Ouzzani, M.; Salt, D.E. High-resolution genome-wide scan of genes, gene-networks and cellular systems impacting the yeast ionome. BMC Genom. 2012, 13, 623. [CrossRef]

222. Maillard, A.; Sorin, E.; Etienne, P.; Diquélou, S.; Koprivova, A.; Kopriva, S.; Arkoun, M.; Gallardo, K.; Turner, M.; Cruz, F.; et al. Non-specific root transport of nutrient gives access to an early nutritional indicator: The case of sulfate and molybdate. PLoS ONE 2016, 11, e0166910. [CrossRef]

223. Sasaki, A.; Yamaji, N.; Ma, J.F. Transporters involved in mineral nutrient uptake in rice. J. Exp. Bot. 2016, 67, 3645-3653. [CrossRef] [PubMed]

224. Hall, J.A.; Williams, L.E. Transition metal transporters in plants. J. Exp. Bot. 2003, 54, 2601-2613. [CrossRef]

225. Williams, L.E.; Pittman, J.K.; Hall, J.L. Emerging mechanisms for heavy metal transport in plants. Biochim. Biophys. Acta Biomembr. 2000, 1465, 104-126. [CrossRef]

226. Axelsen, K.B.; Palmgren, M.G. Evolution of substrate specificities in the P-type ATPase superfamily. J. Mol. Evol. 1998, 46, 84-101. [CrossRef] [PubMed]

227. Papoyan, A.; Leon, V.K. Identification of Thlaspi caerulescens genes that may be involved in heavy metal hyperaccumulation and tolerance. Characterization of a novel heavy metal transporting ATPase. Plant Physiol. 2004, 136, 3814-3823. [CrossRef] [PubMed]

228. Takahashi, R.; Bashir, K.; Ishimaru, Y.; Nishizawa, N.K.; Nakanishi, H. The role of heavy-metal ATPases, HMAs, in zinc and cadmium transport in rice. Plant Signal. Behav. 2012, 7, 1605-1607. [CrossRef] [PubMed]

229. Gravot, A.; Lieutaud, A.; Verret, F.; Auroy, P.; Vavasseur, A.; Richaud, P. AtHMA3, a plant P1B-ATPase, functions as a Cd/Pb transporter in yeast. FEBS Lett. 2004, 561, 22-28. [CrossRef]

230. Morel, M.; Crouzet, J.; Gravot, A.; Auroy, P.; Leonhardt, N.; Vavasseur, A.; Richaud, P. AtHMA3, a P1B-ATPase allowing $\mathrm{Cd} / \mathrm{Zn} / \mathrm{co} / \mathrm{Pb}$ vacuolar storage in Arabidopsis. Plant Physiol. 2009, 149, 894-904. [CrossRef]

231. Eren, E.; Argüello, J.M. Arabidopsis HMA2, a divalent heavy metal-transporting PIB-type ATPase, is involved in cytoplasmic $\mathrm{Zn}^{2+}$ homeostasis. Plant Physiol. 2004, 136, 3712-3723. [CrossRef]

232. Mills, R.F.; Krijger, G.C.; Baccarini, P.J.; Hall, J.L.; Williams, L.E. Functional expression of AtHMA4, a P1B-type ATPase of the $\mathrm{Zn} / \mathrm{Co} / \mathrm{Cd} / \mathrm{Pb}$ subclass. Plant J. 2003, 35, 164-176. [CrossRef]

233. Mills, R.F.; Krijger, G.C.; Baccarini, P.J.; Hall, J.L.; Williams, L.E. The plant P1B-type ATPase AtHMA4 transports Zn and Cd and plays a role in detoxification of transition metals supplied at elevated levels. FEBS Lett. 2005, 579, 783-791. [CrossRef]

234. Verret, F.; Gravot, A.; Auroy, P.; Preveral, S.; Forestier, C.; Vavasseur, A.; Richaud, P. Heavy metal transport by AtHMA4 involves the N-terminal degenerated metal binding domain and the C-terminal His11 stretch. FEBS Lett. 2005, 579, 1515-1522. [CrossRef]

235. Suzuki, M.; Bashir, K.; Inoue, H.; Takahashi, M.; Nakanishi, H.; Nishizawa, N.K. Accumulation of starch in Zn-deficient rice. Rice 2012, 5, 9. [CrossRef]

236. Takahashi, R.; Ishimaru, Y.; Shimo, H.; Ogo, Y.; Senoura, T.; Nishizawa, N.K.; Nakanishi, H. The OsHMA2 transporter is involved in root-to-shoot translocation of $\mathrm{Zn}$ and Cd in rice. Plant Cell Environ. 2012, 35, 1948-1957. [CrossRef]

237. Miyadate, H.; Adachi, S.; Hiraizumi, A.; Tezuka, K.; Nakazawa, N.; Kawamoto, T.; Katou, K.; Kodama, I.; Sakurai, K.; Takahashi, H.; et al. OsHMA3, a $\mathrm{P}_{1 \mathrm{~B}}$-type of ATPase affects root-to-shoot cadmium translocation in rice by mediating efflux into vacuoles. New Phytol. 2011, 189, 190-199. [CrossRef]

238. Deng, F.; Yamaji, N.; Xia, J.; Ma, J.F. A member of the heavy metal P-type ATPase OsHMA5 is involved in xylem loading of copper in rice. Plant. Physiol. 2013, 163, 1353-1362. [CrossRef]

239. Zhiguo, E.; Li, T.T.; Chen, C.; Wang, L. Genome-wide survey and expression analysis of P-1B-ATPases in rice, maize and sorghum. Rice Sci. 2018, 25, 208-217. [CrossRef]

240. Mäser, P.; Thomine, S.; Schroeder, J.I.; Ward, J.M.; Hirschi, K.; Sze, H.; Talke, I.N.; Amtmann, A.; Maathuis, F.J.; Sanders, D.; et al. Phylogenetic relationships within cation transporter families of Arabidopsis. Plant Physiol. 2001, 126, 1646-1667. [CrossRef]

241. Thomine, S.; Wang, R.; Ward, J.M.; Crawford, N.M.; Schroeder, J.I. Cadmium and iron transport by members of a plant metal transporter family in Arabidopsis with homology to Nramp genes. Proc. Natl. Acad. Sci. USA 2000, 97, 4991-4996. [CrossRef]

242. Kolaj-Robin, O.; Russell, D.; Hayes, K.A.; Pembroke, J.T.; Soulimane, T. Cation Diffusion Facilitator family: Structure and function. FEBS Lett. 2015, 589, 1283-1295. [CrossRef] 
243. Montanini, B.; Blaudez, D.; Jeandroz, S.; Sanders, D.; Chalot, M. Phylogenetic and functional analysis of the cation diffusion facilitator (CDF) family: Improved signature and prediction of substrate specificity. BMC Genom. 2007, 8, 107. [CrossRef]

244. Ajeesh Krishna, T.P.; Maharajan, T.; Victor Roch, G.; Ignacimuthu, S.; Antony Ceasar, S. Structure, Function, Regulation and Phylogenetic Relationship of ZIP Family Transporters of Plants. Front. Plant Sci. 2020, 11, 662. [CrossRef]

245. Tiong, J.; McDonald, G.; Genc, Y.; Shirley, N.; Langridge, P.; Huang, C.Y. Increased expression of six ZIP family genes by zinc (Zn) deficiency is associated with enhanced uptake and root-to-shoot translocation of Zn in barley (Hordeum vulgare). New Phytol. 2015, 207, 1097-1109. [CrossRef] [PubMed]

246. Assuncao, A.G.; Herrero, E.; Lin, Y.F.; Huettel, B.; Talukdar, S.; Smaczniak, C.; Immink, R.G.; van Eldik, M.; Fiers, M.; Schat, H.; et al. Arabidopsis thalianatranscription factors bZIP19 and bZIP23 regulate the adaptation to zinc deficiency. Proc. Natl. Acad. Sci. USA 2010, 107, 10296-10301. [CrossRef] [PubMed]

247. Meng, L.; Sun, L.; Tan, L. Progress in ZIP transporter gene family in rice. Yi Chuan 2018, 40, 33-43. [CrossRef] [PubMed]

248. Santos, A.L.D.; Chaves-Silva, S.; Yang, L. Global analysis of the MATE gene family of metabolite transporters in tomato. BMC Plant Biol. 2017, 17, 185. [CrossRef]

249. Wang, L.; Bei, X.; Gao, J.; Li, Y.; Yan, Y.; Hu, Y. The similar and different evolutionary trends of MATE family occurred between rice and Arabidopsis thaliana. BMC Plant Biol. 2016, 16, 207. [CrossRef]

250. Zhu, H.; Wu, J.; Jiang, Y.; Jin, J.; Zhou, W.E.I.; Wang, Y.U.; Han, G.; Zhao, Y.; Cheng, B. Genome wide analysis of MATE-type gene family in maize reveals microsynteny and their expression patterns under aluminum treatment. J. Genet. 2016, 95, 691-704 [CrossRef]

251. Zhao, J.; Dixon, R.A. MATE transporters facilitate vacuolar uptake of epicatechin $3^{\prime}$-O-glucoside for proanthocyanidin biosynthesis in Medicago truncatula and Arabidopsis. Plant Cell 2009, 21, 2323-2340. [CrossRef]

252. Ogawa, I.; Nakanishi, H.; Mori, S.; Nishizawa, N.K. Time course analysis of gene regulation under cadmium stress in rice. Plant Soil 2009, 325, 97-108. [CrossRef]

253. Guidotti, G. ATP transport and ABC proteins. Chem. Biol. 1996, 3, 703-706. [CrossRef]

254. Garcia, O.; Philippe, B.; Cyrille, F.; Elie, D. Inventory and comparative analysis of rice and Arabidopsis ATP-binding cassette (ABC) systems. J. Mol. Biol. 2004, 343, 249-265. [CrossRef]

255. Kuromori, T.; Eriko, S.; Kazuo, S. Arabidopsis mutants of AtABCG22, an ABC transporter gene, increase water transpiration and drought susceptibility. Plant J. 2011, 67, 885-894. [CrossRef]

256. Rice, A.J.; Aekyung, P.; Heather, W.P. Diversity in ABC transporters: Type I, II and III importers. Crit. Rev. Biochem. Mol. Biol. 2014, 49, 426-437. [CrossRef]

257. Boominathan, R.; Doran, P.M. Cadmium tolerance and antioxidative defenses in hairy roots of the cadmium hyperaccumulator, Thlaspi caerulescens. Biotechnol. Bioengin. 2003, 83, 158-167. [CrossRef]

258. Park, J.; Song, W.Y.; Ko, D.; Eom, Y.; Hansen, T.H.; Schiller, M.; Lee, T.G.; Martinoia, E.; Lee, Y. The phytochelatin transporters AtABCC1 and AtABCC2 mediate tolerance to cadmium and mercury. Plant J. 2012, 69, 278-288. [CrossRef]

259. Larsen, P.B.; Geisler, M.J.; Jones, C.A.; Williams, K.M.; Cancel, J.D. ALS3 encodes a phloem-localized ABC transporter-like protein that is required for aluminum tolerance in Arabidopsis. Plant J. 2005, 41, 353-363. [CrossRef]

260. Sonah, H.; Deshmukh, R.K.; Labbé, C.; Bélanger, R.R. Analysis of aquaporins in Brassicaceae species reveals high-level of conservation and dynamic role against biotic and abiotic stress in canola. Sci. Rep. 2017, 7, 2771. [CrossRef]

261. Ma, J.F.; Yamaji, N.; Mitani, N.; Tamai, K.; Konishi, S.; Fujiwara, T.; Katsuhara, M.; Yano, M. An efflux transporter of silicon in rice. Nature 2007, 448, 209-212. [CrossRef]

262. Vivancos, J.; Deshmukh, R.; Grégoire, C.; Rémus-Borel, W.; Belzile, F.; Bélanger, R.R. Identification and characterization of silicon efflux transporters in horsetail (Equisetum arvense). J. Plant Physiol. 2016, 200, 82-89. [CrossRef]

263. Chiba, Y.; Mitani, N.; Yamaji, N.; Ma, J.F. HvLsi1 is a silicon influx transporter in barley. Plant J. 2009, 57, 810-818. [CrossRef]

264. Deshmukh, R.K.; Vivancos, J.; Guérin, V.; Sonah, H.; Labbé, C.; Belzile, F.; Bélanger, R.R. Identification and functional characterization of silicon transporters in soybean using comparative genomics of major intrinsic proteins in Arabidopsis and rice. Plant Mol. Biol. 2013, 83, 303-315. [CrossRef]

265. Mitani, N.; Chiba, Y.; Yamaji, N.; Ma, J.F. Identification and characterization of maize and barley Lsi2-like silicon efflux transporters reveals a distinct silicon uptake system from that in rice. Plant Cell 2009, 21, 2133-2142. [CrossRef]

266. Montpetit, J.; Vivancos, J.; Mitani-Ueno, N.; Yamaji, N.; Rémus-Borel, W.; Belzile, F.; Ma, J.F.; Bélanger, R.R. Cloning, functional characterization and heterologous expression of TaLsi1, a wheat silicon transporter gene. Plant Mol. Biol. 2012, $79,35-46$. [CrossRef] [PubMed]

267. Salt, D.E. Update on ionomics. Plant Physiol. 2004, 136, 2451-2456. [CrossRef]

268. Arbona, V.; Manzi, M.; Ollas, C.D.; Gómez-Cadenas, A. Metabolomics as a tool to investigate abiotic stress tolerance in plants. Int. J. Mol. Sci. 2013, 14, 4885-4911. [CrossRef] [PubMed]

269. Bajwa, A.A.; Farooq, M.; Nawaz, A. Seed priming with sorghum extracts and benzyl aminopurine improves the tolerance against salt stress in wheat (Triticum aestivum L.). Physiol. Mol. Biol. Plants 2018, 24, 239-249. [CrossRef]

270. Bowne, J.B.; Erwin, T.A.; Juttner, J.; Schnurbusch, T.; Langridge, P.; Bacic, A.; Roessner, U. Drought responses of leaf tissues from wheat cultivars of differing drought tolerance at the metabolite level. Mol. Plant 2012, 5, 418-429. [CrossRef] [PubMed]

271. Li, S.M.; Shi, W.M. Quantitative characterization of nitrogen regulation of OsAMT1; 1, OsAMT1; 2, and OsAMT2; 2 expression in rice seedlings. Russ. J. Plant Physiol. 2006, 53, 837-843. [CrossRef] 
272. Narayanan, S.; Tamura, P.J.; Roth, M.R.; Prasad, P.V.; Welti, R. Wheat leaf lipids during heat stress: I. High day and night temperatures result in major lipid alterations. Plant Cell Environ. 2016, 39, 787-803. [CrossRef]

273. Pant, B.D.; Burgos, A.; Pant, P.; Cuadros-Inostroza, A.; Willmitzer, L.; Scheible, W.R. The transcription factor PHR1 regulates lipid remodeling and triacylglycerol accumulation in Arabidopsis thaliana during phosphorus starvation. J. Exp. Bot. 2015, 66, 1907-1918. [CrossRef]

274. Skirycz, A.; De Bodt, S.; Obata, T.; De Clercq, I.; Claeys, H.; De Rycke, R.; Andriankaja, M.; Van Aken, O.; van Breusegem, F.; Fernie, A.R.; et al. Developmental stage specificity and the role of mitochondrial metabolism in the response of Arabidopsis leaves to prolonged mild osmotic stress. Plant Physiol. 2010, 152, 226-244. [CrossRef]

275. Zhu, G.; Wang, S.; Huang, Z.; Zhang, S.; Liao, Q.; Zhang, C.; Lin, T.; Qin, M.; Peng, M.; Yang, C.; et al. Rewiring of the fruit metabolome in tomato breeding. Cell 2018, 172, 249-261. [CrossRef] [PubMed]

276. Ichihashi, Y.; Date, Y.; Shino, A.; Shimizu, T.; Shibata, A.; Kumaishi, K.; Funahashi, F.; Wakayama, K.; Yamazaki, K.; Umezawa, A.; et al. Multi-omics analysis on an agroecosystem reveals the significant role of organic nitrogen to increase agricultural crop yield. Proc. Natl. Acad. Sci. USA 2020, 117, 14552-14560. [CrossRef] [PubMed]

277. Moreno, J.C.; Martinez-Jaime, S.; Kosmacz, M.; Sokolowska, E.M.; Schulz, P.; Fischer, A.; Luzarowska, U.; Havaux, M.; Skirycz, A. A multi-OMICs approach sheds light on the higher yield phenotype and enhanced abiotic stress tolerance in tobacco lines expressing the carrot lycopene $\beta$-cyclase1 gene. Front. Plant Sci. 2021, 12. [CrossRef] [PubMed]

278. Li, C.; Xiangchi, Z.; Chao, L.; Wen, W.; Cheng, L. Ionomic and metabolic responses to drought stress in elite wheat seedlings under two phosphorus levels. Res. Sq. 2021, 1-20. [CrossRef]

279. Huang, X.Y.; Salt, D.E. Plant ionomics: From elemental profiling to environmental adaptation. Mol. Plant 2016, 9, 787-797. [CrossRef]

280. Guo, H.; Li, S.; Min, W.; Ye, J.; Hou, Z. Ionomic and transcriptomic analyses of two cotton cultivars (Gossypium hirsutum L.) provide insights into the ion balance mechanism of cotton under salt stress. PLoS ONE 2019, 14, e0226776. [CrossRef]

281. Guo, R.; Shi, L.; Yan, C.; Zhong, X.; Gu, F.; Liu, Q.; Xia, X.; Li, H. Ionomic and metabolic responses to neutral salt or alkaline salt stresses in maize (Zea mays L.) seedlings. BMC Plant Biol. 2017, 17, 41. [CrossRef]

282. Ho, W.W.H.; Hill, C.B.; Doblin, M.S.; Shelden, M.C.; van de Meene, A.; Rupasinghe, T.; Bacic, A.; Roessner, U. Integrative multi-omics analyses of barley rootzones under salinity stress reveal two distinctive salt tolerance mechanisms. Plant. Comm. 2020, 1, 100031. [CrossRef]

283. Groskinsky, D.K.; Syaifullah, S.J.; Roitsch, T. Integration of multi-omics techniques and physiological phenotyping within a holistic phenomics approach to study senescence in model and crop plants. J. Exp. Bot. 2018, 69, 825-844. [CrossRef]

284. Raza, A.; Razzaq, A.; Mehmood, S.S.; Hussain, M.A.; Wei, S.; He, H.; Zaman, Q.U.; Xuekun, Z.; Hasanuzzaman, M. Omics: The way forward to enhance abiotic stress tolerance in Brassica napus L. GM Crop. Food 2021, 12, 251-281. [CrossRef]

285. Fischer, N.; Efferth, T. The impact of "omics" technologies for grapevine (Vitis vinifera) research. J. Berr. Res. 2020, 1-15. [CrossRef] 